\title{
Short term persistence of human papillomavirus and risk of cervical precancer and cancer: population based cohort study
}

\author{
Philip E Castle, investigator, ${ }^{1}$ Ana Cecilia Rodríguez, medical epidemiologist, ${ }^{3}$ Robert D Burk, professor, ${ }^{4}$ \\ Rolando Herrero, medical epidemiologist, ${ }^{3}$ Sholom Wacholder, senior investigator, ${ }^{1}$ Mario Alfaro, \\ cytopathologist, ${ }^{3}$ Jorge Morales, colposcopist, ${ }^{3}$ Diego Guillen, pathologist,, Mark E Sherman, pathologist, \\ Diane Solomon, pathologist, ${ }^{2}$ Mark Schiffman, senior investigator, ${ }^{1}$ for the Proyecto Epidemiológico \\ Guanacaste (PEG) Groupfor the Proyecto Epidemiológico Guanacaste (PEG) Group
}

Division of Cancer Epidemiology and Genetics, National Cancer Institute, National Institutes of Health, DHHS, Bethesda, MD 20892, USA

${ }^{2}$ Division of Cancer Prevention, National Cancer Institute, National Institutes of Health, DHHS, Bethesda, MD 20892, USA

${ }^{3}$ Proyecto Epidemiológico Guanacaste, INCIEN

SA Foundation, San José, Costa Rica

${ }^{4}$ Albert Einstein Cancer Center, Albert Einstein College of Medicine, Bronx, NY 10461, USA Correspondence to: PE Castle castlep@mail.nih.gov

Cite this as: $B M J$ 2009;339:b2569 doi:10.1136/bmj.b2569

\section{ABSTRACT}

Objective To evaluate the cumulative incidence of cervical intraepithelial neoplasia II or worse (grade I+) or cervical intraepithelial neoplasia grade III+ after short term persistence of prevalently detected carcinogenic human papillomavirus (HPV).

Design Population based cohort study.

Setting Guanacaste, Costa Rica.

Participants 2282 sexually active women actively followed after enrolment.

Main outcome measures Primary end points: three year and five year cumulative incidence of histologically confirmed cervical intraepithelial neoplasia grade II+ $(n=70)$. Cervical specimens collected at each visit tested for more than 40 HPV genotypes. HPV 16, 18, 26, 31, 33, $35,39,45,51,52,56,58,59,66,68,73$, and 82 were considered the primary carcinogenic genotypes.

Results Women who tested positive for a carcinogenic HPV at enrolment and after about one year (9-21 months) (positive/positive) had a three year cumulative incidence of cervical intraepithelial neoplasia grade II+ of $17.0 \%$ (95\% confidence interval $12.1 \%$ to $22.0 \%$ ). Those who tested negative/positive (3.4\%, $0.1 \%$ to $6.8 \%$ ), positive/ negative $(1.2 \%,-0.2 \%$ to $2.5 \%)$, and negative/negative $(0.5 \%, 0.1 \%$ to $0.9 \%)$ were at a significantly lower risk. There was little difference in the cumulative incidence of cervical intraepithelial neoplasia grade II+ between testing positive twice for any carcinogenic HPV genotype (same genotype or different genotypes) $v$ testing positive twice for the same carcinogenic genotype $(17.0 \% \mathrm{~V}$ $21.3 \%$, respectively). Short term persistence of HPV 16 strongly predicted cervical intraepithelial neoplasia grade $1+$, with a three year cumulative incidence of $40.8 \%$ ( $26.4 \%$ to $55.1 \%$ ). Similar patterns were observed for the five year cumulative incidence of grade $\mathrm{II}+$ and for three year and five year cumulative incidence of grade III+. Conclusions Short term persistence of a prevalently detected carcinogenic HPV infection, especially HPV 16, strongly predicts a subsequent diagnosis of cervical intraepithelial neoplasia II+ over the next few years.

\section{INTRODUCTION}

Based on the central role of persistent infections with carcinogenic human papillomavirus (HPV) in cervical cancer, DNA testing for carcinogenic genotypes of HPV has recently been introduced into cervical cancer screening. HPV testing is more reliable ${ }^{12}$ and more sensitive but less specific than routinely performed cytology for detection of cervical intraepithelial neoplasia grade III and cancer (grade III+) or grade II+. ${ }^{3-7}$ HPV testing might soon be widely accepted as an alternative to routine cytology for cervical cancer screening. ${ }^{8}$

The enthusiasm for using carcinogenic HPV testing in primary screening, however, has been tempered by its lower predictive value or absolute risk for cervical intraepithelial neoplasia grade II+ or III+ after a positive result compared with abnormal cytology. Even in older women the prevalence of self limited carcinogenic HPV infection can reach $10 \%$, with only a minority of at risk women developing grade II+.

Some possible ways to improve the positive predictive value after HPV primary screening have been suggested. One is to use cytology as a reflex test for women positive for carcinogenic HPV because definitely abnormal cytology is more specific for cervical intraepithelial neoplasia grade III+. ${ }^{9}$ Another possibility is HPV genotyping to target the most carcinogenic genotypes and permit the tracking of viral persistence. Separate detection of HPV 16 and 18 in cytologically normal women aged 30 and older might be useful for identifying those at an increased risk of cervical intraepithelial neoplasia grade II+. ${ }^{10} 11$ Those who test positive might benefit from immediate colposcopy, while those who test negative for both could wait a year before being screened again. ${ }^{1011}$

Given the fundamental role of persistent HPV infection in cervical carcinogenesis, its reliable measurement could increase the accuracy of cervical cancer screening by further distinguishing carcinogenic HPV infections that pose the greatest risk from less 
risky infections because they have already been cleared or suppressed by the immune system. Carcinogenic HPV types that are found prevalently on screening tend to clear quickly, with about $50 \%$ undetectable within 6-12 months and most being undetectable by two years. ${ }^{12}{ }^{13}$ A recent systematic review and metaanalysis of the risk posed by HPV persistence after prevalently detected infections found that the summary estimated relative risk for cervical precancer with persistent versus transient infection was 14.7 , increasing to 42.9 with persistence for about one year. ${ }^{14}$ Therefore, monitoring a prevalently detected HPV infection for a year or more might be useful. ${ }^{18}$ Women with one year persistence of a specific HPV genotype remain at an increased risk of cervical precancer and cancer for several years, even if colposcopic evaluation at time zero initially fails to detect disease. ${ }^{5}$

Using data generated from a population based study, we examined the possible utility of measuring viral persistence over about a one year interval ( 9-21 months) and the risk of precancer and cancer over the subsequent years of follow-up. We examined whether measuring short term persistence of prevalently detected HPV infections quantifies the risk of cervical precancer and cancer, and whether different test configurations - that is, measuring persistence of a specific HPV genotype for all versus only the most carcinogenic genotypes (HPV 16 and 18)-differentiate between women at lesser and greater risk of cervical precancer and cancer.

\section{METHODS}

\section{Study population}

This population based cohort study included participants from Guanacaste, Costa Rica, enrolled between June 1993 and December 1994. ${ }^{131516}$ After randomly selecting about $20 \%$ of the census tracts in the region (11 742 women), 10769 were eligible for the study. Of these, $10049(93.3 \%)$ provided informed written consent. Detailed methods of recruitment, screening, and follow-up have been previously published. ${ }^{1516}$ Our cohort comprised 8545 women with baseline HPV testing and an intact cervix (fig 1). We excluded women who had undergone hysterectomy $(n=630)$, were virgins $(\mathrm{n}=583)$, or refused a pelvic examination $(\mathrm{n}=291)$. Highly trained study nurses conducted screening visits and collected cervical specimens.

We referred to colposcopy those women who, at the enrolment visit, had equivocal or definitely abnormal cytology (on any of three methods), abnormal direct visual examinations, or the appearance of cervical abnormalities on review of their Cervigrams, a static photographic image of the cervix. To permit individualised care outside the study protocol, we excluded from active follow-up 290 women who had some evidence of cervical intraepithelial neoplasia grade II+ at enrolment, whether or not this was confirmed histologically by colposcopy and directed biopsies.

As previously described, ${ }^{15}$ we actively followed a subcohort of sexually active women $(2626 / 8545,30.7 \%)$ at intervals of six or 12 months to explore risk factors for incident cervical intraepithelial neoplasia grade II+. (We included 25 women who did not have a pelvic examination at enrolment and four women who had not yet reported becoming sexually active but were older than 26 in the active follow-up, but we excluded them from this analysis based on the criteria described below.) Choice of the subcohort was based on the perceived risk of developing cervical intraepithelial neoplasia grade II+ according to screening results and colposcopy; $60.0 \%$ of these 2626 women underwent colposcopic evaluation (at a median of 95 days, mean 113 days), while others were included in the subcohort because they had five or more lifetime sexual partners or high viral load HPV infection as determined by an early HPV assay (HC Tube Test, Digene, Gaithersburg, $\mathrm{MD})$. A random sample of all women with no screening abnormalities and without these risk factors ${ }^{15}(\mathrm{n}=540)$ was also chosen for active follow-up. Thus, this subcohort represented a mixture of higher risk women (based on enrolment screening results and sexual behaviour) and was supplemented by a random sample of the remaining cohort population.

Women were initially followed annually, except for the 492 with low grade intraepithelial lesion or cervical intraepithelial neoplasia grade I at baseline, who were followed at six month intervals for increased safety of the participants. During the course of the study, as in regular clinical practice, women were shifted to

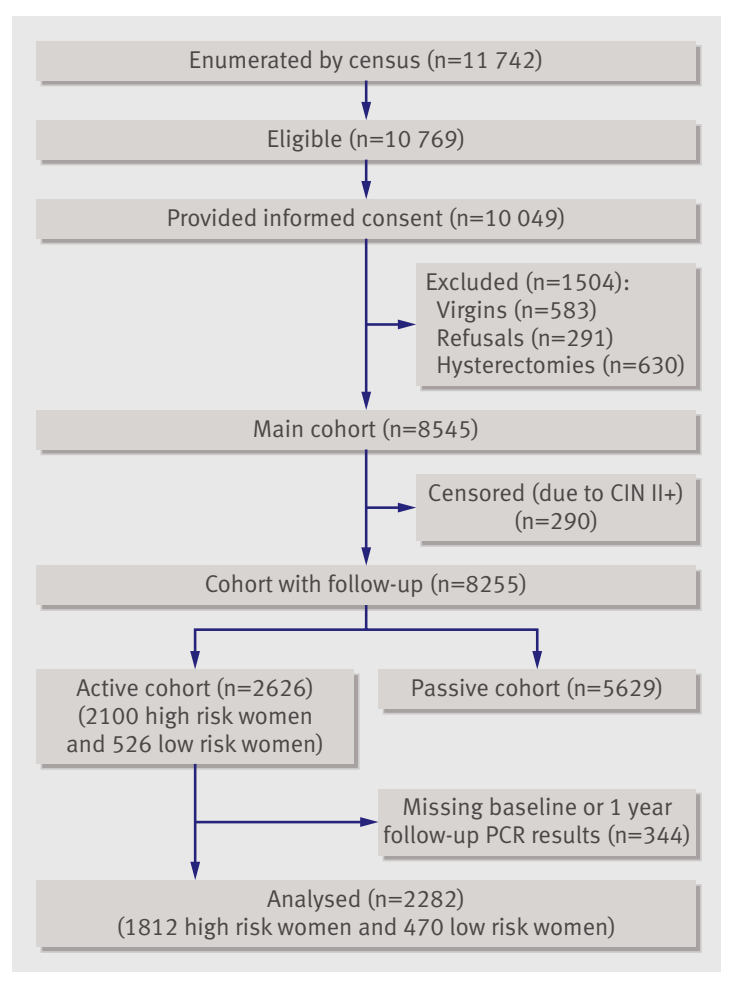

Fig 1 | Flow of women through trial. High risk refers to women with positive results on screening or with risk factors (such as five or more lifetime sexual partners) for HPV or cervical neoplasia. Low risk refers to women with negative results and no risk factors. $\mathrm{CIN}=$ cervical intraepithelial neoplasia; $\mathrm{PCR}=$ polymerase chain reaction 
accelerated screening every six months if they presented with low grade cytological or histological abnormalities.

HPV genotyping with polymerase chain reaction was performed on stored specimens. Of the 2626 eligible actively followed women, $2282(86.9 \%)$ attended a one year follow-up visit (9-21 months) and had adequate polymerase chain reaction results at both enrolment and at their one year follow-up visit to be included in this analysis of short term persistence. This analysis included 1812 of 2100 of women $(86.3 \%)$ with either screening abnormalities or risk factors ("high risk" women) and 470 of 540 randomly selected women $(79.6 \%)$ with no screening abnormalities and no risk factors ("low risk" women).

Throughout the study, women with cytological, visual, or Cervigram evidence of high grade cervical neoplasia were referred to colposcopy performed by an expert colposcopist (JM). At exit, to ensure the safety of women leaving the cohort, we referred women with abnormal (atypical squamous cells of uncertain significance (ASCUS) or low grade squamous intraepithelial lesions (LSIL)) cytological interpretation; a positive Cervigram ( $\mathrm{P} 0$ or $\mathrm{P} 1)$ in either of the last two screening visits; or persistent carcinogenic HPV infection or HPV 16 or HPV 18 at either of the last two screening visits. Finally, a $6.25 \%$ random sample of the cohort was referred for an exit colposcopy.

\section{Collection of specimens}

Two exfoliative cervical specimens were obtained during a single pelvic examination at baseline and all follow-up visits. ${ }^{1516}$ The first specimen was collected with a Cervex cytology broom directed at the cervical os. After preparation of conventional smears, the remaining cells were placed into PreservCyt (Cytyc) medium, from which thin layer cytology slides (ThinPrep, Cytyc Corp, Marlborough, MA) were made. A second cervical specimen was similarly collected immediately after the first by using a Dacron swab that was then stored in specimen transport medium (STM; Qiagen, Gaithersburg, MD).

\section{HPV DNA testing}

Polymerase chain reaction testing was done with DNA prepared from the stored specimen collected at each visit. To amplify HPV DNA, we used a MY09/M11 L1 degenerate primer polymerase chain reaction (MY09/11 PCR) method as described previously. ${ }^{17}$ Dot blot hybridisation of polymerase chain reaction products for HPV genotype specific detection was conducted with genotype specific oligonucleotide probes for HPV genotypes 2, 6, 11, 13, 16, 18, 26, 31-35, 39, $40,42-45,51-9,61,62,66-74,81-85$, and $89 .{ }^{17}$ Probes for genotypes $2,13,34,42-44,54,57,69,74$, and 82 were also combined in dot blot hybridisations for detection of rare genotypes (dot blot mix). Specimens that were HPV positive after Southern blot hybridisation with a radiolabelled generic probe mix, but were not positive for any specific probe, were considered to be positive for uncharacterised genotypes. For consistency with a related analysis, ${ }^{18} \mathrm{HPV}$ genotypes $16,18,26,31,33,35,39,45,51,52,56,58,59,66,68$, 73 , and 82 were considered as primary carcinogens. Finally, the HPV test results were assigned hierarchically to a HPV risk group based on the relative importance (carcinogenicity) of each genotype ${ }^{1920}$ : positive for HPV 16; positive for HPV 18 but negative for HPV 16; positive for any carcinogenic HPV genotypes but negative for HPV 16 and HPV 18 (carcinogenic HPV excluding HPV 16 and HPV 18); and negative for carcinogenic HPV genotypes. We abbreviated this hierarchy as HPV 16 positive $>$ HPV 18 positive $>$ other carcinogenic HPV genotypes >negative.

\section{Pathology}

All women with possible cervical intraepithelial neoplasia grade II+ at any time, detected by any screening technique, and including a nurse's concern on gross examination, were referred to colposcopy with guided biopsy of visible lesions and censored from further follow-up. Women diagnosed locally on initial histological evaluation as grade II+ were treated by large loop excision or by inpatient surgery as clinically indicated. MES and DS reviewed histology diagnosed locally as grade II or worse. The final assignment of cases as invasive cancer, grade III, grade II, or < grade II was made according to an algorithm based on the independent masked reviews. Occasionally a few difficult cases were adjudicated by joint review with consideration of cytological slides as well as histology.

\section{Statistical methods}

We used cervical intraepithelial neoplasia grade II+ as our primary end point because grade II was the threshold for treatment. We also used grade III+ in some analyses, recognising that grade II represents an equivocal diagnosis of cervical precancer ${ }^{2122}$ whereas grade III is a more definite cervical cancer precursor and is less likely to regress.

We were primarily interested in looking at the simple cumulative incidence and 95\% confidence intervals of cervical intraepithelial neoplasia II+ or III+ (see appendix on bmj.com for further details of the statistical analysis) for different combinations of test results to simulate different possible formulations of HPV tests: detection of any carcinogenic HPV without individual identification of the HPV genotype (Hybrid Capture 2, Qiagen, Gaithersburg, MD, USA; Amplicor, Roche Diagnostics, Indianapolis, IN, USA, currently approved for use in Europe only); partial HPV genotyping in which HPV 16 and 18 are detected separately in addition to aggregate detection of all carcinogenic genotypes (Cervista HPV HR Molecular Assay, Third Wave Technologies, Madison, WI, USA, currently approved for use in Europe only with HPV 16/18 Molecular Assay, research use only); and full individual HPV genotyping for all carcinogenic HPV genotypes (Linear Array, Roche Molecular Systems, Alameda, CA, USA, currently approved for use in Europe only). We combined test results for individual genotypes to simulate pools of genotypes. Results were 
Table 1|Characteristics of subcohort of 2282 women (median age 40.1)

\begin{tabular}{|c|c|}
\hline & No (\%) \\
\hline \multicolumn{2}{|l|}{ Oral contraceptive use: } \\
\hline Data missing & $1(0.0)$ \\
\hline Never used & $798(35.0)$ \\
\hline Former user & $983(43.1)$ \\
\hline Current user & $500(21.9)$ \\
\hline \multicolumn{2}{|l|}{ Barrier contraceptive use: } \\
\hline Data missing & $1(0.0)$ \\
\hline Never used & $1278(56.0)$ \\
\hline Former user & $770(33.7)$ \\
\hline Current user & $233(10.2)$ \\
\hline \multicolumn{2}{|l|}{ No of live births } \\
\hline 0 & $127(5.6)$ \\
\hline $1-2$ & $757(33.2)$ \\
\hline $3-4$ & $630(27.6)$ \\
\hline$\geq 5$ & $768(33.7)$ \\
\hline \multicolumn{2}{|l|}{ Marital status: } \\
\hline Married & $1762(77.2)$ \\
\hline Separate/divorced & $132(5.8)$ \\
\hline Widowed & $85(3.7)$ \\
\hline Single & $303(13.3)$ \\
\hline \multicolumn{2}{|l|}{ Cervical smear before enrolment: } \\
\hline Yes & $2047(89.7)$ \\
\hline No & $233(10.2)$ \\
\hline Do not know & $2(0.1)$ \\
\hline \multicolumn{2}{|l|}{ Abnormal smear result before enrolment: } \\
\hline Yes & $524(23.0)$ \\
\hline No & $1523(66.7)$ \\
\hline Never had one/do not know & $235(10.3)$ \\
\hline \multicolumn{2}{|l|}{ HPV status at 1 year: } \\
\hline Persistent HPV 16 & $55(2.4)$ \\
\hline Persistent HPV 18 & $18(0.8)$ \\
\hline $\begin{array}{l}\text { Persistent for specific carcinogenic } \\
\text { genotype (not HPV 16/18) }\end{array}$ & $136(6.0)$ \\
\hline $\begin{array}{l}\text { Persistent for carcinogenic HPV } \\
\text { (not specific genotype) }\end{array}$ & $51(2.2)$ \\
\hline Acquired carcinogenic HPV & $125(5.5)$ \\
\hline Cleared carcinogenic HPV & $282(12.4)$ \\
\hline Negative (and negative at baseline) & $1615(70.8)$ \\
\hline
\end{tabular}

categorised hierarchically according to risk, with HPV persistence as the top category, such that women who had persistence of any genotype were classified as having persistence regardless of whether other genotypes were present at either time point. We also calculated cumulative incidence rate ratios with $95 \%$ confidence intervals for cervical intraepithelial neoplasia grade II + end points by using women who tested positive for carcinogenic HPV at enrolment and negative at the follow-up visit as the reference group because we were interested in differentiating between low risk and high risk women who tested positive for carcinogenic HPV at enrolment. We used simple cumulative incidence curves, rather than more complex modelling, to describe the data because there was no appreciable difference by HPV status in the number of women who underwent censoring treatment or an exit visit
(90-95\%) (data not shown) and most women attended their annual visits (80\%-90\% per visit), with only small differences in attendance by HPV status.

We examined patterns of cumulative incidence stratified by age $(<30$ and $\geq 30)$. We also evaluated the impact of having a colposcopic evaluation during the enrolment period or as the result of the six month follow-up visit for 492 women with low grade squamous intraepithelial lesions or cervical intraepithelial neoplasia grade I; $11(2.2 \%)$ women seen at the six month follow-up were censored for cervical abnormalities and excluded from this analysis. Finally, we evaluated by stratification the impact of having nonnormal cytology (atypical squamous cells of undetermined significance or more severe) versus negative cytology at the 9-21 month follow-up visit.

\section{RESULTS}

Table 1 shows the basic enrolment demographics of the subcohort of 2282 women included in this analysis. The median age was 37.0 years (mean 40.1, range 1891). Most women were current $(21.9 \%)$ or former $(43.1 \%)$ users of oral contraceptives, were married $(77.2 \%)$, and had had at least one previous smear test $(89.7 \%)$ at the time of enrolment, although the accuracy of that screening was typically not optimal. ${ }^{16}$ Of the 2282 women, $542(23.8 \%)$ tested positive for carcinogenic HPV at enrolment.

As we have previously reported, ${ }^{18}$ more than half $(282,52.0 \%)$ of the 542 women who were positive for one or more carcinogenic HPV genotypes at enrolment cleared their infection(s) after a year. Among the 209 (38.6\% of the 542) women with at least short term persistent carcinogenic HPV infection, 55 (26.3\%) had persistent HPV 16, 18 (8.6\%) had persistent HPV 18, and the 136 remaining $(65.1 \%)$ had genotype specific persistence for other carcinogenic genotypes. Twenty five of $209(12.0 \%)$ women had more than one persistent carcinogenic HPV infection for one year or more.

Table 2 shows the numbers of women by HPV status and disease outcome (cervical intraepithelial neoplasia grade II+). Forty six of the 260 women (17.7\%) who tested repeatedly positive for carcinogenic HPV were diagnosed with grade II+ during follow-up. By comparison, $4.8 \%(\mathrm{n}=6)$ of women who were negative and then positive for carcinogenic HPV, $1.8 \%(n=5)$ of women who were positive and then negative, and $0.8 \%$ $(\mathrm{n}=13)$ of women who tested negative twice were diagnosed with grade II+ during follow-up. There were no appreciable differences in the percentage of women with grade II+ for a given HPV status between high risk and low risk women, only differences in the distribution of women with a given HPV status $(\mathrm{P}<0.001)$. We therefore consider the population of 2282 in aggregate in our subsequent analyses.

Table 3 shows the three year and five year cumulative incidence of cervical intraepithelial neoplasia grade II+ and grade III+ after the 9-21 month followup visit. We first examined the cumulative incidence of grade II+ for paired test results, at enrolment, and 
Table 2| HPV status and outcomes for 2282 women included in analysis

\begin{tabular}{|c|c|c|c|c|c|c|}
\hline \multirow[b]{2}{*}{ HPV status } & \multicolumn{2}{|c|}{ All women } & \multicolumn{2}{|c|}{ High risk women* } & \multicolumn{2}{|c|}{ Low risk women† } \\
\hline & No of women & $\begin{array}{c}\text { No (\%) } \\
\text { with CIN II+ }\end{array}$ & No of women & $\begin{array}{c}\text { No (\%) } \\
\text { with CIN II+ }\end{array}$ & No of women & $\begin{array}{c}\text { No (\%) } \\
\text { with CIN II+ }\end{array}$ \\
\hline \multicolumn{7}{|c|}{ Repeatedly positive for carcinogenic HPV (Pos/Pos): } \\
\hline Total & 260 & $46(17.7)$ & 246 & $44(17.9)$ & 14 & $2(14.3)$ \\
\hline HPV 16 persistence & 55 & $20(36.4)$ & 52 & $19(36.5)$ & 3 & $1(33.3)$ \\
\hline HPV 18 persistence & 18 & $5(27.8)$ & 18 & $5(27.8)$ & 0 & 0 \\
\hline Type specific persistence & 136 & $21(15.4)$ & 126 & $20(15.9)$ & 10 & $1(10.0)$ \\
\hline Non-specific persistence & 51 & $0(0.0)$ & 50 & $0(0.0)$ & 1 & $0(0.0)$ \\
\hline Acquisition (Neg/Pos) & 125 & $6(4.8)$ & 111 & $5(4.5)$ & 14 & $1(7.1)$ \\
\hline Clearance (Pos/Neg) & 282 & $5(1.8)$ & 263 & $4(1.5)$ & 19 & $1(5.3)$ \\
\hline Neg/Neg & 1615 & $13(0.8)$ & 1192 & $11(0.9)$ & 423 & $2(0.5)$ \\
\hline Total & 2282 & $70(3.1)$ & 1812 & $64(3.5)$ & 470 & $6(1.3)$ \\
\hline
\end{tabular}

*Screen positive or had risk factors (such as five or more lifetime sexual partners) for HPV or cervical neoplasia.

$\dagger$ Screen negative and did not have above risk factors.

9-21 months later for carcinogenic HPV (table 3, fig 2). The three year cumulative incidence of grade II+ was $17.0 \%$ (95\% confidence interval $12.1 \%$ to $22.0 \%$ ) for women who tested positive for carcinogenic HPV twice (positive/positive), regardless of whether they were the same carcinogenic types (table 3 , fig 2 ). The three year cumulative incidence of cervical intraepithelial neoplasia grade II+ for each of the other combinations of test results was $3.4 \%(0.1 \%$ to $6.8 \%)$ for negative/positive (acquired), $1.2 \%$ ( $-0.2 \%$ to $2.5 \%)$ for positive/negative (cleared), and $0.5 \%(0.1 \%$ to $0.9 \%)$ for negative/negative. The five year cumulative incidence of grade II+ for positive/positive, negative/positive, positive/negative, and negative/negative was $23.7 \%$ (14.8\% to $32.6 \%), 4.4 \%(-0.3 \%$ to $5.1 \%), 1.6(0.04 \%$ to $3.1 \%)$, and $0.5 \%(0.1 \%$ to $0.9 \%)$, respectively. We observed no appreciable differences in the cumulative incidence of grade II+ when we stratified by the median time interval ( $\leq 408 v>408$ days) between the enrolment and follow-up visits (for example, the three year cumulative incidence of grade II+ for women testing positive for carcinogenic HPV twice in $\leq 408$ and $>$ 408 days was $16.90 \%(9.91 \%$ to $23.89 \%)$ and $17.21 \%$ (10.07\% to $24.34 \%$ ) (data not shown).

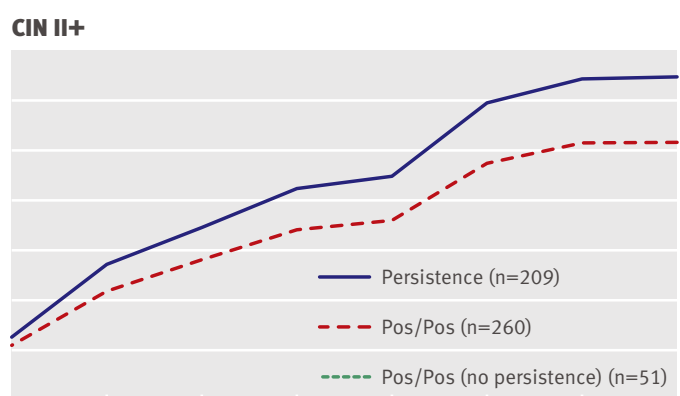

CIN III+

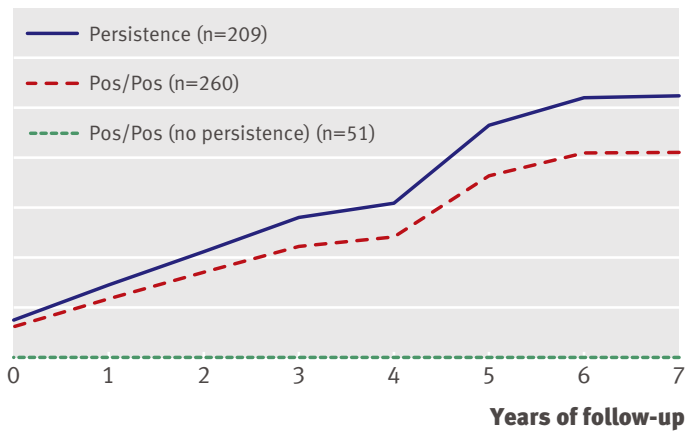

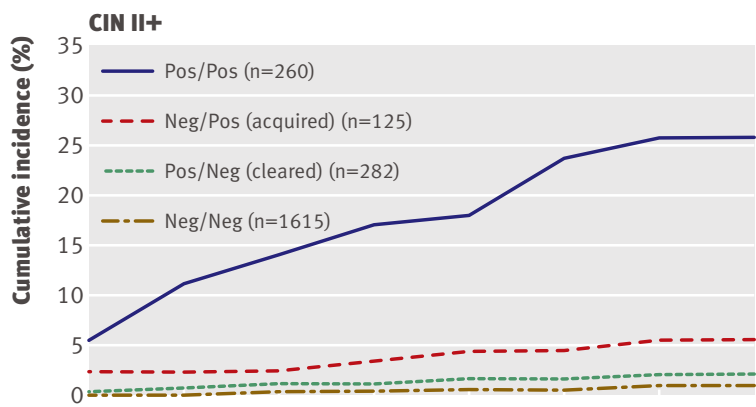

CIN III+

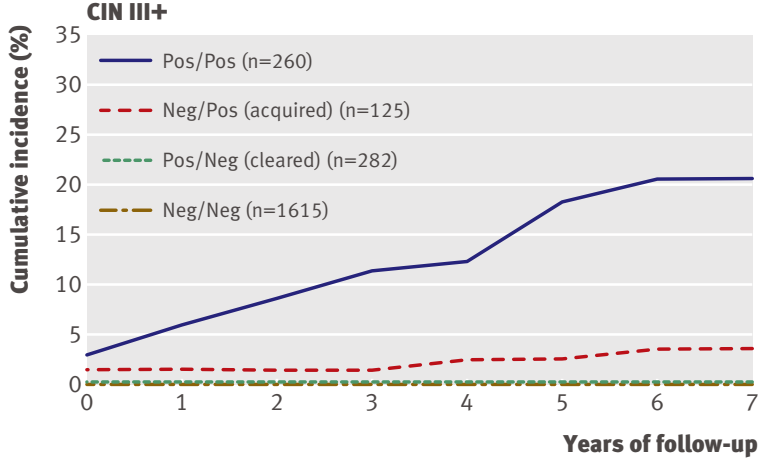

Fig 2 | Cumulative incidence of cervical intraepithelial neoplasia (CIN) grade II or worse (II+) and grade III+ after repeat measurements of carcinogenic human papillomavirus (HPV) at about one year interval (9-21 months) in women who tested positive for carcinogenic HPV twice (Pos/Pos), positive for carcinogenic HPV at enrolment but negative at follow-up ("cleared"), negative for carcinogenic HPV at enrolment but positive at follow-up ("acquired"), or negative at both time points (Neg/Neg). In right panels the Pos/Pos category is further stratified into those with at least one persistent carcinogenic HPV genotype (persistence) $v$ positive for different carcinogenic HPV genotypes (Pos/Pos (no persistence)), with unstratified Pos/Pos curves shown for reference. Time 0 * indicates start time of analysis, 9-21 months after enrolment 
Table 3 |Three year and 5 year cumulative incidence rates of cervical intraepithelial neoplasia grade II or more severe (CIN II+) and CIN III+ after repeat measurements of carcinogenic human papillomavirus (HPV) at about 1 year interval (9-21 months)

\begin{tabular}{|c|c|c|c|c|c|c|c|c|c|c|c|c|}
\hline & \multirow[b]{3}{*}{$\begin{array}{c}\text { No of } \\
\text { women }\end{array}$} & \multicolumn{6}{|c|}{ CIN II+ } & \multicolumn{5}{|c|}{ CIN III+ } \\
\hline & & \multicolumn{3}{|c|}{3 year } & \multicolumn{3}{|c|}{5 year } & \multicolumn{2}{|c|}{3 year } & \multicolumn{3}{|c|}{5 year } \\
\hline & & $\begin{array}{l}\text { No of } \\
\text { cases }\end{array}$ & $\begin{array}{c}\text { Rate* }^{\star} \\
(95 \% \mathrm{Cl})\end{array}$ & $\begin{array}{c}\text { Rate ratio } † \\
(95 \% \mathrm{Cl})\end{array}$ & $\begin{array}{l}\text { No of } \\
\text { cases }\end{array}$ & $\begin{array}{l}\text { Rate }^{\star} \\
(95 \% \mathrm{Cl})\end{array}$ & $\begin{array}{c}\text { Rate ratio } † \\
(95 \% \mathrm{Cl})\end{array}$ & $\begin{array}{l}\text { No of } \\
\text { cases }\end{array}$ & $\begin{array}{c}\text { Rate* }^{\star} \\
(95 \% \mathrm{Cl})\end{array}$ & $\begin{array}{l}\text { No of } \\
\text { cases }\end{array}$ & $\begin{array}{c}\text { Rate* }^{\star} \\
(95 \% \mathrm{Cl})\end{array}$ & $\begin{array}{c}\text { Rate ratio } † \\
(95 \% \mathrm{Cl})\end{array}$ \\
\hline $\begin{array}{l}\text { Carcinogenic HPV } \\
\text { persistence }\end{array}$ & 260 & 38 & $\begin{array}{l}17.04(12.05 \\
\text { to } 22.03)\end{array}$ & $\begin{array}{c}14.53(4.53 \\
\text { to } 46.58)\end{array}$ & 42 & $\begin{array}{c}23.69(14.75 \\
\text { to } 32.62)\end{array}$ & $\begin{array}{c}14.99(5.28 \\
\text { to } 42.62)\end{array}$ & 24 & $\begin{array}{c}11.27(6.97 \\
\text { to } 15.57)\end{array}$ & 28 & $\begin{array}{c}18.38(7.02 \\
\text { to } 15.10)\end{array}$ & $\begin{array}{l}44.66(5.94 \\
\text { to } 335.88)\end{array}$ \\
\hline $\begin{array}{l}\text { Specific genotype } \\
\text { persistence }\end{array}$ & 209 & 38 & $\begin{array}{l}21.26(15.18 \\
\text { to } 27.33)\end{array}$ & $\begin{array}{c}18.12(5.66 \\
\text { to } 57.99)\end{array}$ & 42 & $\begin{array}{l}29.90(18.65 \\
\text { to } 41.14)\end{array}$ & $\begin{array}{c}18.92(6.66 \\
\text { to } 53.76)\end{array}$ & 24 & $\begin{array}{c}14.22(8.86 \\
\text { to } 19.57)\end{array}$ & 28 & $\begin{array}{c}23.63(11.88 \\
\text { to } 35.57)\end{array}$ & $\begin{array}{l}57.42(7.63 \\
\text { to } 432.02)\end{array}$ \\
\hline Non-persistence & 51 & 0 & 0.00 & 0.00 & 0 & 0.00 & 0.00 & 0 & 0.00 & 0 & 0.00 & 0.00 \\
\hline HP 16 persistence & 55 & 19 & $\begin{array}{l}40.77(26.40 \\
\text { to } 55.13)\end{array}$ & $\begin{array}{c}34.75(10.66 \\
\text { to } 113.26)\end{array}$ & 19 & $\begin{array}{l}40.77(26.40 \\
\text { to } 55.13)\end{array}$ & $\begin{array}{c}25.81(9.16 \\
\text { to } 72.71)\end{array}$ & 13 & $\begin{array}{c}30.57(16.42 \\
\text { to } 44.71)\end{array}$ & 13 & $\begin{array}{c}30.57(16.42 \\
\text { to } 44.71)\end{array}$ & $\begin{array}{c}74.28(9.95 \\
\text { to } 554.32)\end{array}$ \\
\hline HPV 18 persistence & 18 & 3 & $\begin{array}{c}17.46(-0.58 \\
\text { to } 35.50)\end{array}$ & $\begin{array}{c}14.88(3.22 \\
\text { to } 68.70)\end{array}$ & 3 & $\begin{array}{c}17.46(-0.58 \\
\text { to } 35.50)\end{array}$ & $\begin{array}{c}11.05(2.67 \\
\text { to } 45.73)\end{array}$ & 1 & $\begin{array}{c}5.56(-5.03 \\
\text { to } 16.14)\end{array}$ & 1 & $\begin{array}{c}5.56(-5.03 \\
\text { to } 16.14)\end{array}$ & $\begin{array}{c}13.50(0.88 \\
-207.03)\end{array}$ \\
\hline $\begin{array}{l}\text { Carcinogenic HPV } \\
\text { persistence (not } 16 \\
\text { and 18) }\end{array}$ & 187 & 16 & $\begin{array}{c}10.00(5.32 \\
\text { to } 14.68)\end{array}$ & $\begin{array}{l}8.53(2.51 \\
\text { to } 28.91)\end{array}$ & 20 & $\begin{array}{c}18.19(8.02 \\
\text { to } 28.37)\end{array}$ & $\begin{array}{c}11.52(3.75 \\
\text { to } 35.41)\end{array}$ & 10 & $\begin{array}{l}6.23(2.52 \\
\text { to } 10.23)\end{array}$ & 14 & $\begin{array}{c}14.90(4.66 \\
\text { to } 25.13)\end{array}$ & $\begin{array}{c}36.20(4.55 \\
\text { to } 287.76)\end{array}$ \\
\hline Acquisition & 125 & 4 & $\begin{array}{c}3.44(0.10 \\
\text { to } 6.78)\end{array}$ & $\begin{array}{l}2.93(0.66 \\
\text { to } 12.98)\end{array}$ & 5 & $\begin{array}{l}4.44(-0.28 \\
\text { to } 5.08)\end{array}$ & $\begin{array}{c}2.81(0.76 \\
\text { to } 10.35)\end{array}$ & 2 & $\begin{array}{c}1.60(-0.60 \\
\text { to } 3.80)\end{array}$ & 3 & $\begin{array}{c}2.63(-0.28 \\
\text { to } 5.08)\end{array}$ & $\begin{array}{l}6.38(0.67 \\
\text { to } 60.93)\end{array}$ \\
\hline $\begin{array}{l}\text { Clearance } \\
\text { (reference) } \ddagger\end{array}$ & 282 & 3 & $\begin{array}{c}1.17(-0.15 \\
\text { to } 2.50)\end{array}$ & 1.00 & 4 & $\begin{array}{c}1.58(0.04 \\
\text { to } 3.12)\end{array}$ & 1.00 & 0 & 0.00 & 1 & $\begin{array}{c}0.41(-0.39 \\
\text { to } 1.22)\end{array}$ & 1.00 \\
\hline HPV negative & 1615 & 7 & $\begin{array}{l}0.49(0.13 \\
\text { to } 0.85)\end{array}$ & $\begin{array}{l}0.42(0.11 \\
\text { to } 1.61)\end{array}$ & 7 & $\begin{array}{l}0.49(0.13 \\
\text { to } 0.85)\end{array}$ & $\begin{array}{l}0.31(0.09 \\
\text { to } 1.06)\end{array}$ & 4 & $\begin{array}{l}0.28(0.01 \\
\text { to } 0.56)\end{array}$ & 4 & $\begin{array}{l}0.28(0.01 \\
\text { to } 0.56)\end{array}$ & $\begin{array}{l}0.69(0.08 \\
\text { to } 6.12)\end{array}$ \\
\hline
\end{tabular}

*Cumulative incidence rates.

†Cumulative incidence rate ratio; when no events of CIN II+ occurred in reference group, this could not be calculated (NA).

fWomen who tested positive and then negative for carcinogenic HPV ("clearance").

Similar relative patterns were observed when we used cervical intraepithelial neoplasia grade III+ as the end point (table 3, fig 2). For example, the three year cumulative incidence of grade III+ for positive/ positive, negative/positive, positive/negative, and negative/negative was $11.3 \%(7.0 \%$ to $15.6 \%), 1.6 \%$ $(-0.6 \%$ to $38.0 \%), 0 \%$ (confidence interval not available), and $0.3 \%(0.01 \%$ to $0.6 \%)$, respectively.

Among those women who tested repeatedly positive for carcinogenic HPV, we were interested in the cumulative incidence of cervical intraepithelial neoplasia grade II+ among all women who tested positive twice for carcinogenic HPV compared with the subgroups of women who tested positive twice for carcinogenic HPV and had HPV genotype specific persistence and those tested positive for different HPV genotypes (that is, one HPV genotype cleared and another was acquired). In this population with median age of 40.1, well past the peak of HPV incidence, we found that most women repeatedly positive for carcinogenic HPV had HPV genotype specific persistence (209/ $260,80.4 \%$ ). In this small group of women who tested positive for carcinogenic HPV at both time points but for different genotypes, none developed $\geq$ grade II. Therefore, among those who tested repeatedly positive for carcinogenic HPV, all incident grade II+ and grade III+ diagnoses during follow-up were linked to HPV genotype specific persistence (table 3 , fig 2 ).

Of the 1615 women who tested negative for any carcinogenic HPV genotype at both time points, 104 $(6.4 \%)$ had short term persistence for non-carcinogenic HPV (data not shown). Only one of these women, however, was diagnosed as a case (cervical intraepithelial neoplasia grade III) over the entire follow-up, yielding a seven year risk for grade II+ and grade III+ of 1.2\% (95\% confidence interval $-1.1 \%$ to $3.6 \%$ ), and this was probably the result of an incident HPV 31 infection acquired after the 9-21 month interval that persisted almost four years before the grade III diagnosis.

We repeated our analysis to examine how age $(<30$ $(\mathrm{n}=612$, median age 25$) v \geq 30$ years $(\mathrm{n}=1670$, median age 42) modified these patterns (table 4). The three year and five year cumulative incidence of cervical intraepithelial neoplasia grade II+ for women $<30$ was $19.0 \%$ (8.3\% to $24.3 \%)$ and $20.3 \%$ (11.5\% to $29.0 \%$, respectively. For women $\geq 30$ years the incidence was $15.8 \%(9.7 \%$ to $21.9 \%)$ and $25.9 \%(12.6 \%$ to $39.2 \%$, respectively. Cumulative incidences after other detection patterns (acquisition, clearance) were much lower than in women repeatedly testing positive for carcinogenic HPV.

Among women with persistently positive results for carcinogenic HPV, a greater proportion of those aged $\geq 30(143 / 163,87.7 \%)$ had persistence of specific genotypes ( $v$ different genotypes) than those aged $<30$ (66/ $97,68.0 \%)(\mathrm{P}<0.001$, Fisher's exact) (table 4). Thus, there was qualitatively a greater difference in the cumulative incidence of cervical intraepithelial neoplasia grade II+ among all women who tested repeatedly positive for carcinogenic HPV from the subset of women persistently positive for specific HPV genotypes aged $<30$ than in those aged $\geq 30$. We found similar patterns in cumulative incidence, with wider confidence intervals because of smaller numbers, for grade III+ (data not shown).

We also considered separate detection of HPV 16 and HPV 18 and the risk of cervical precancer and cancer (table 3, fig 3) after classifying our HPV test 
results hierarchically according to importance in causing cancer (HPV 16 positive $>\mathrm{HPV} 18$ positive $>$ other carcinogenic HPV genotypes $>$ negative). The three and five year cumulative incidence of cervical intraepithelial neoplasia II+ was $40.8 \%(26.4 \%$ to $55.1 \%)$ after short term HPV 16 persistence (table 3, fig 3) and $17.5 \%(-0.6 \%$ to $35.5 \%)$ after short term HPV 18 persistence. Repeatedly testing positive for other carcinogenic HPV genotypes as a pool predicted three and five year risks for grade II+ of 10.0\% (5.3\% to 14.7\%) and $18.2 \%$ (8.0\% to $28.4 \%)$, respectively.

Among women aged $<30$, short term persistence of HPV 16 was highly predictive of a subsequent diagnosis of cervical intraepithelial neoplasia grade II+, with a three (and five) year risk of $65.9 \%$ (40.4\% to $91.5 \%)$ (table 4, fig 3). By comparison, among women aged $\geq 30$, the three (and five) year risk after short term HPV 16 persistence was $27.2 \%$ (11.1\% to $43.3 \%)$ (table 4, fig 3). There was no significant difference in the intensity of follow-up (median number of days between visits) by HPV status, although women who were in higher risk HPV groups (such as persistent HPV 16) naturally had fewer follow-up visits on average because of censoring treatments for diagnoses of grade II+ ( $\mathrm{P}<0.001$ for trend) (data not shown).

We compared the cumulative incidence of cervical intraepithelial neoplasia grade II+ among all women who tested positive twice for carcinogenic HPV genotypes other than HPV 16 and 18 with the subgroups of women who persistently had specific HPV genotypes and those tested positive for different HPV genotypes (see supplemental figure on bmj.com). Again we found that only a small percentage $(51 / 187,27.3 \%)$ of women repeatedly positive for carcinogenic HPV did not have persistence of specific genotypes, although it is noteworthy that the number of women without viral persistence was the same as when we considered all carcinogenic HPV genotypes. A greater proportion of women aged $\geq 30(99 / 119,83.2 \%)$ who repeatedly tested positive for carcinogenic HPV had persistence of specific HPV genotype ( $v$ positive for different HPV genotypes) compared with women aged $<30(37 / 68$, $54.4 \%) \quad(\mathrm{P}<0.001$, Fisher's exact). Consequently, among women aged $<30$, the cumulative incidence of cervical intraepithelial neoplasia grade II+ (see supplemental figure on bmj.com) among the entire group of women who tested positive twice for carcinogenic HPV genotypes other than HPV 16 and 18 was almost half that for the subgroup of women with confirmed viral persistence of specific HPV genotypes. For example, the three year cumulative incidence of grade II+ among women aged $<30$ was $7.1 \%(0.4 \%$ to $13.8 \%)$ in those who tested positive twice for carcinogenic HPV genotypes other than HPV 16 and 18 and 28.8\% (3.9 to 212.0) in the subgroup of women with confirmed persistence of specific HPV genotypes.

We were also interested in whether having abnormal cytology (atypical squamous cells of undetermined significance or worse) versus normal cytology at the follow-up visit modified the observed patterns of HPV persistence and risk of cervical intraepithelial neoplasia grade II+ or III+. As shown in table 5, the patterns observed for other groups were qualitatively similar except that women with atypical squamous cells of undetermined significance or worse generally had higher cumulative incidence of disease than those who had normal cytology, most noticeably in the earlier follow-up times.

Finally, we considered whether short term viral persistence strongly predicted cervical intraepithelial neoplasia grade II+ after colposcopy (conducted during the enrolment phase) without findings of grade II+ (table 6). We again observed a high risk of grade II+ and III+ with short term HPV viral persistence, especially for HPV 16, whether or not a woman had recently undergone colposcopy to rule out cervical intraepithelial neoplasia grade II+.

\section{DISCUSSION}

Testing for short term HPV persistence might be clinically useful for assessing the risk of cervical intraepithelial neoplasia grade II+ among women who test positive for carcinogenic HPV. We carried out our study in a subcohort of women enrolled in our population based cohort in Guanacaste, Costa Rica. We focused on measurements over about one year ( 9-21 months) because there was previous evidence that measuring persistence over that duration begins to differentiate between transient and clinically relevant HPV infections. ${ }^{52324}$ In the United States, one year is the recommended follow-up time for women who have an abnormal screening result but do not have concurrent, colposcopically detected cervical intraepithelial neoplasia grade II+. ${ }^{11}$

Women who tested positive twice for carcinogenic HPV had an increased risk of grade II+ and III+, while the risk in women who test negative for carcinogenic HPV at either or both time points was low. We did not observe any appreciable differences in the risks between those women with a shorter and longer time intervals between the enrolment and follow-up visit, suggesting that these findings are robust to variability in which women return for follow-up testing. Among those who tested positive twice for carcinogenic HPV, all subsequent diagnoses of cervical intraepithelial neoplasia grade II+ were linked to persistence of a specific HPV genotype. With the exception of HPV 16 and possibly HPV 18, however, detection of persistence of a specific genotype did not differentiate women at risk for grade II+ qualitatively better than repeated detection of an aggregate of carcinogenic HPV types. Few women had HPV 18 at enrolment, which led to unstable estimates of related cumulative incidence of grade II+. Yet, the weight of evidence regarding the utility of HPV 18 detection, ${ }^{1025}$ including it being the second leading cause of cancer and its strong association with adenocarcinoma, ${ }^{20}$ which is on the rise in the $\mathrm{US}^{26}$ and Europe ${ }^{27}$ and might be more difficult to detect by cytology based screening, would argue in favour of its separate detection.

In summary, repeat testing (versus one time tests) might further divide the population into low risk and 
Table 4 |Three year and 5 year cumulative incidence rates of cervical intraepithelial neoplasia grade II or more severe (CIN II+) and CIN III+ after repeat measurements of carcinogenic human papillomavirus (HPV) at about 1 year interval (9-21 months) according to age of women

\begin{tabular}{|c|c|c|c|c|c|c|c|c|c|c|c|c|}
\hline & \multirow[b]{3}{*}{$\begin{array}{c}\text { No of } \\
\text { women }\end{array}$} & \multicolumn{6}{|c|}{ CIN II+ } & \multicolumn{5}{|c|}{ CIN III+ } \\
\hline & & \multicolumn{3}{|c|}{3 year } & \multicolumn{3}{|c|}{5 year } & \multicolumn{2}{|r|}{3 year } & \multicolumn{3}{|c|}{5 year } \\
\hline & & $\begin{array}{l}\text { No of } \\
\text { cases }\end{array}$ & $\begin{array}{c}\text { Rate* }^{\star} \\
(95 \% \mathrm{Cl})\end{array}$ & $\begin{array}{c}\text { Rate ratio } † \\
(95 \% \mathrm{Cl})\end{array}$ & $\begin{array}{l}\text { No of } \\
\text { cases }\end{array}$ & $\begin{array}{c}\text { Rate* }^{\star} \\
(95 \% \mathrm{Cl})\end{array}$ & $\begin{array}{c}\text { Rate ratio } † \\
(95 \% \mathrm{Cl})\end{array}$ & $\begin{array}{l}\text { No of } \\
\text { cases }\end{array}$ & $\begin{array}{l}\text { Rate* }^{\star} \\
(95 \% \mathrm{Cl})\end{array}$ & $\begin{array}{l}\text { No of } \\
\text { cases }\end{array}$ & $\begin{array}{l}\text { Rate* }^{\star} \\
(95 \% \mathrm{Cl})\end{array}$ & $\begin{array}{c}\text { Rate ratio† } \\
(95 \% \mathrm{Cl})\end{array}$ \\
\hline \multicolumn{13}{|l|}{ Age $<30$} \\
\hline $\begin{array}{l}\text { Carcinogenic HPV } \\
\text { persistence }\end{array}$ & 97 & 16 & $\begin{array}{c}19.02(8.33 \\
\text { to } 24.23)\end{array}$ & $\begin{array}{l}19.40(2.62 \\
\text { to } 143.59)\end{array}$ & 17 & $\begin{array}{c}20.29(11.52 \\
\text { to } 29.06)\end{array}$ & $\begin{array}{c}10.60(2.51 \\
\text { to } 44.70)\end{array}$ & 8 & $\begin{array}{c}10.06(3.31 \\
\text { to } 16.82)\end{array}$ & 9 & $\begin{array}{c}11.47(4.28 \\
\text { to } 18.65)\end{array}$ & $\begin{array}{c}12.15(1.57 \\
\text { to } 94.32)\end{array}$ \\
\hline $\begin{array}{l}\text { Specific genotype } \\
\text { persistence }\end{array}$ & 66 & 16 & $\begin{array}{l}28.22(16.18 \\
\text { to } 40.27)\end{array}$ & $\begin{array}{l}28.79(3.91 \\
\text { to } 211.99)\end{array}$ & 17 & $\begin{array}{l}30.11(17.83 \\
\text { to } 42.40)\end{array}$ & $\begin{array}{c}15.73(3.76 \\
\text { to } 65.87)\end{array}$ & 8 & $\begin{array}{c}15.25(5.21 \\
\text { to } 25.28)\end{array}$ & 9 & $\begin{array}{c}17.48(6.79 \\
\text { to } 28.16)\end{array}$ & $\begin{array}{l}18.53(2.40 \\
\text { to } 143.08)\end{array}$ \\
\hline Non-persistence & 31 & 0 & 0.000 & 0.00 & 0 & 0.00 & 0.00 & 0 & 0.00 & 0 & 0.00 & 0.00 \\
\hline HP 16 persistence & 22 & 11 & $\begin{array}{c}65.91(40.36 \\
\text { to } 91.46)\end{array}$ & $\begin{array}{l}67.23(9.20 \\
\text { to } 491.08)\end{array}$ & 11 & $\begin{array}{c}65.91(40.36 \\
\text { to } 91.46)\end{array}$ & $\begin{array}{l}34.43(8.27 \\
\text { to } 143.35)\end{array}$ & 6 & $\begin{array}{c}40.34(11.39 \\
\text { to } 69.29)\end{array}$ & 6 & $\begin{array}{c}40.34(11.39 \\
\text { to } 69.29)\end{array}$ & $\begin{array}{c}42.76(5.35 \\
\text { to } 341.78)\end{array}$ \\
\hline HPV 18 persistence & 7 & 1 & $\begin{array}{c}14.29(-11.6 \\
\text { to } 40.21)\end{array}$ & $\begin{array}{l}14.57(1.02 \\
\text { to } 209.15)\end{array}$ & 1 & $\begin{array}{c}14.29(-11.6 \\
\text { to } 40.21)\end{array}$ & $\begin{array}{l}7.46(0.77 \\
\text { to } 72.62)\end{array}$ & 0 & 0.00 & 0 & 0.00 & 0.00 \\
\hline $\begin{array}{l}\text { Carcinogenic HPV } \\
\text { persistence } \\
\text { (not } 16 \text { and 18) } \\
\end{array}$ & 68 & 4 & $\begin{array}{l}7.05(0.35 \\
\text { to } 13.75)\end{array}$ & $\begin{array}{l}7.19(0.82 \\
\text { to } 62.93)\end{array}$ & 5 & $\begin{array}{l}8.77(1.39 \\
\text { to } 16.14)\end{array}$ & $\begin{array}{l}4.58(0.92 \\
\text { to } 22.91)\end{array}$ & 2 & $\begin{array}{l}3.77(-1.36 \\
\text { to } 8.90)\end{array}$ & 3 & $\begin{array}{l}5.56(-0.55 \\
\text { to } 11.67)\end{array}$ & $\begin{array}{l}5.89(0.63 \\
\text { to } 55.28)\end{array}$ \\
\hline Acquisition & 56 & 2 & $\begin{array}{c}3.57(-1.29 \\
\text { to } 8.43)\end{array}$ & $\begin{array}{l}3.64(0.34 \\
\text { to } 39.29)\end{array}$ & 3 & $\begin{array}{c}5.92(-0.65 \\
\text { to } 12.50)\end{array}$ & $\begin{array}{l}3.09(0.53 \\
\text { to } 18.08)\end{array}$ & 1 & $\begin{array}{l}1.79(-1.68 \\
\text { to } 5.25)\end{array}$ & 2 & $\begin{array}{c}4.18(-1.56 \\
\text { to } 9.92)\end{array}$ & $\begin{array}{l}4.43(0.41 \\
\text { to } 48.15)\end{array}$ \\
\hline Clearance (reference) $\ddagger$ & 125 & 1 & $\begin{array}{c}0.98(-0.93 \\
\text { to } 2.89)\end{array}$ & 1.00 & 2 & $\begin{array}{c}1.91(-0.71 \\
\text { to } 4.54)\end{array}$ & 1.00 & 0 & 0.00 & 1 & $\begin{array}{c}0.94(-0.90 \\
\text { to } 2.78)\end{array}$ & 1.00 \\
\hline HPV negative & 334 & 2 & $\begin{array}{l}0.77(-0.29 \\
\text { to } 1.82)\end{array}$ & $\begin{array}{l}0.78(0.07 \\
\text { to } 8.53)\end{array}$ & 2 & $\begin{array}{l}0.77(-0.29 \\
\quad \text { to } 1.82)\end{array}$ & $\begin{array}{l}0.40(0.06 \\
\text { to } 2.80)\end{array}$ & 1 & $\begin{array}{c}0.38(-0.37 \\
\text { to } 1.13)\end{array}$ & 1 & $\begin{array}{l}0.38(-0.37 \\
\text { to } 1.13)\end{array}$ & $\begin{array}{c}0.41(0.03 \\
\text { to } 6.43)\end{array}$ \\
\hline \multicolumn{13}{|l|}{ Age $\geq 30$} \\
\hline $\begin{array}{l}\text { Carcinogenic HPV } \\
\text { persistence }\end{array}$ & 163 & 22 & $\begin{array}{c}15.79(9.69 \\
\text { to } 21.89)\end{array}$ & $\begin{array}{c}11.64(2.78 \\
\text { to } 48.75)\end{array}$ & 25 & $\begin{array}{l}25.88(12.56 \\
\text { to } 39.19)\end{array}$ & $\begin{array}{c}19.07(4.37 \\
\text { to } 83.12)\end{array}$ & 16 & $\begin{array}{c}11.84(6.34 \\
\text { to } 17.34)\end{array}$ & 19 & $\begin{array}{c}22.40(8.75 \\
\text { to } 36.05)\end{array}$ & NA \\
\hline $\begin{array}{l}\text { Specific genotype } \\
\text { persistence }\end{array}$ & 143 & 22 & $\begin{array}{c}18.11(11.21 \\
\text { to } 25.02)\end{array}$ & $\begin{array}{c}13.35(3.19 \\
\text { to } 55.84)\end{array}$ & 25 & $\begin{array}{c}30.62(14.59 \\
\text { to } 44.65)\end{array}$ & $\begin{array}{c}22.56(5.16 \\
\text { to } 98.66)\end{array}$ & 16 & $\begin{array}{c}13.67(7.38 \\
\text { to } 19.96)\end{array}$ & 19 & $\begin{array}{c}26.85(10.24 \\
\text { to } 43.46)\end{array}$ & NA \\
\hline Non-persistence & 20 & 0 & 0.00 & 0.00 & 0 & 0.00 & 0.00 & 0 & 0.00 & 0 & 0.00 & NA \\
\hline HP 16 persistence & 33 & 8 & $\begin{array}{l}27.18(11.09 \\
\text { to } 43.26)\end{array}$ & $\begin{array}{c}20.03(4.46 \\
\text { to } 89.84)\end{array}$ & 8 & $\begin{array}{l}27.18(11.09 \\
\text { to } 43.26)\end{array}$ & $\begin{array}{c}20.03(4.46 \\
\text { to } 89.84)\end{array}$ & 7 & $\begin{array}{c}24.67(8.80 \\
\text { to } 40.53)\end{array}$ & 7 & $\begin{array}{c}24.67(8.80 \\
\text { to } 40.53)\end{array}$ & NA \\
\hline HPV 18 persistence & 11 & 2 & $\begin{array}{c}20.45(-5.14 \\
\text { to } 46.05)\end{array}$ & $\begin{array}{c}15.07(2.34 \\
\text { to } 97.06)\end{array}$ & 2 & $\begin{array}{c}20.45(-5.14 \\
\text { to } 46.05)\end{array}$ & $\begin{array}{c}15.07(2.34 \\
\text { to } 97.06)\end{array}$ & 1 & $\begin{array}{c}9.09(-7.90 \\
\text { to } 26.08)\end{array}$ & 1 & $\begin{array}{c}9.09(-7.90 \\
\text { to } 26.08)\end{array}$ & NA \\
\hline $\begin{array}{l}\text { Carcinogenic HPV } \\
\text { persistence (not } 16 \text { and } \\
\text { 18) }\end{array}$ & 119 & 12 & $\begin{array}{c}11.68(5.42 \\
\text { to } 17.93)\end{array}$ & $\begin{array}{l}8.60(1.96 \\
\text { to } 37.79)\end{array}$ & 15 & $\begin{array}{c}23.08(8.52 \\
\text { to } 37.63)\end{array}$ & $\begin{array}{c}17.01(3.73 \\
\text { to } 77.51)\end{array}$ & 8 & $\begin{array}{l}7.87(2.58 \\
\text { to } 13.16)\end{array}$ & 11 & $\begin{array}{c}19.77(4.95 \\
\text { to } 34.85)\end{array}$ & NA \\
\hline Acquisition & 69 & 2 & $\begin{array}{c}3.21(-1.19 \\
\text { to } 7.61)\end{array}$ & $\begin{array}{l}2.36(0.34 \\
\text { to } 16.54)\end{array}$ & 2 & $\begin{array}{c}3.21(-1.19 \\
\text { to } 7.61)\end{array}$ & $\begin{array}{l}2.36(0.34 \\
\text { to } 16.54)\end{array}$ & 1 & $\begin{array}{c}1.45(-1.37 \\
\text { to } 4.27)\end{array}$ & 1 & $\begin{array}{c}1.45(-1.37 \\
\text { to } 4.27)\end{array}$ & NA \\
\hline Clearance (reference) $\ddagger$ & 157 & 2 & $\begin{array}{l}1.36(-0.51 \\
\text { to } 3.23)\end{array}$ & 1.00 & 2 & $\begin{array}{c}1.36(-0.51 \\
\text { to } 3.23)\end{array}$ & 1.00 & 0 & 0.00 & 0 & 0.00 & NA \\
\hline HPV negative & 1281 & 5 & $\begin{array}{l}0.43(0.05 \\
\text { to } 0.81)\end{array}$ & $\begin{array}{l}0.32(0.06 \\
\text { to } 1.62)\end{array}$ & 5 & $\begin{array}{l}0.43(0.05 \\
\text { to } 0.81)\end{array}$ & $\begin{array}{l}0.32(0.06 \\
\text { to } 1.62)\end{array}$ & 3 & $\begin{array}{l}0.26(-0.03 \\
\text { to } 0.56)\end{array}$ & 3 & $\begin{array}{l}0.26(-0.03 \\
\text { to } 0.56)\end{array}$ & NA \\
\hline
\end{tabular}

*Cumulative incidence rates.

tCumulative incidence rate ratio; when no events of CIN II+ occurred in reference group, this could not be calculated (NA).

fWomen who tested positive and then negative for carcinogenic HPV ("clearance").

high risk for incipient precancerous lesions. Detection of HPV 16 and might be particularly useful to identify women at risk for cervical precancer.

\section{Previous studies}

Previous studies that looked at repeat testing with polymerase chain reaction ${ }^{28}$ and by hybrid capture $\mathrm{II}^{29}$ over a two year interval found similar patterns and similar associations and risks. In our analysis, however, women who first had positive results on testing and then had negative results seemed to have a level of risk that was similar to those who tested negative twice, whereas women who tested positive then negative on hybrid capture II in the study by Kjaër et $\mathrm{al}^{29}$ had a level of risk that was somewhat higher than those who tested negative twice. We cannot explain the discrepancy between the two reports.

We observed, as have others, ${ }^{28}$ that persistence of a specific HPV genotype predicted a risk of cervical intraepithelial neoplasia grade II+ only slightly more strongly than the risk of testing positive twice for the pool of carcinogenic HPV over a short term interval, especially at older ages. The greater likelihood of testing positive for carcinogenic HPV because of different HPV genotypes and persistence of a specific genotype was greater in women aged $<30$ than in women aged $\geq 30$, perhaps because more younger women have prevalently detected transient infections ${ }^{30}$ and are more likely to clear and then acquire a new infection than older women. This suggestion is supported by the 

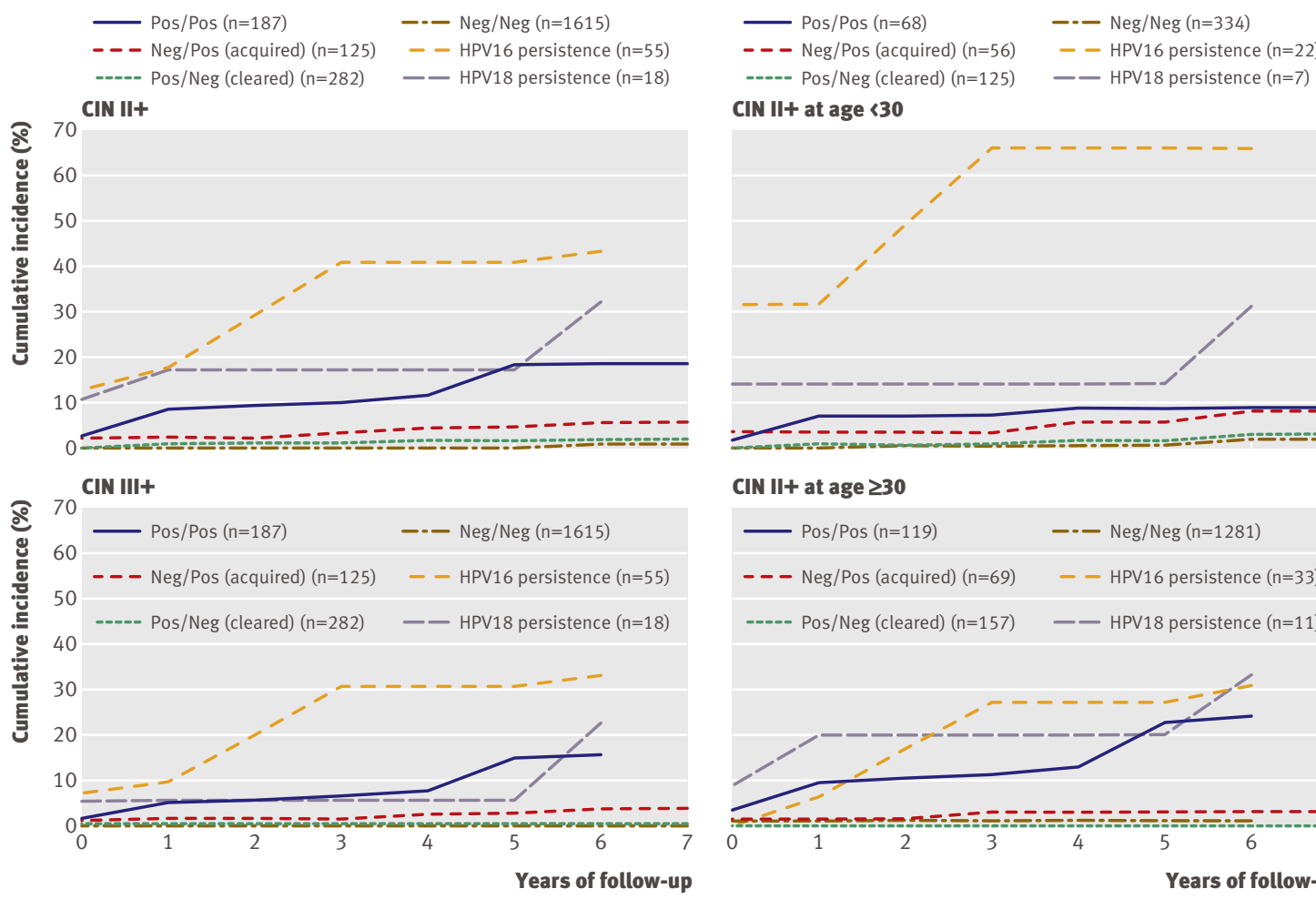

CIN II+ at age $<30$

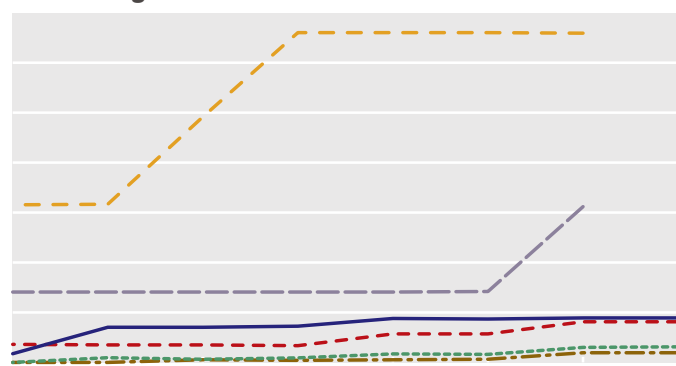

CIN II+ at age $\geq 30$

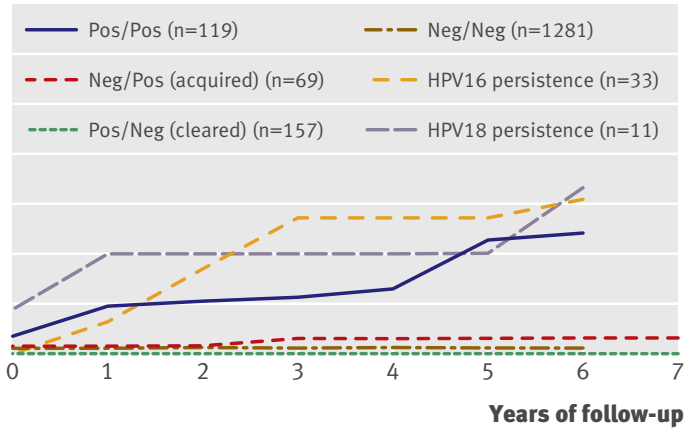

Fig 3 | Cumulative incidence of cervical intraepithelial neoplasia (CIN) grade II or more severe (grade II+) or grade III+ after repeat measurements of human papillomavirus (HPV) at about one year interval (9-21 months) in women who had persistent HPV 16, had persistent HPV 18, tested positive for carcinogenic HPV twice (Pos/Pos), tested positive for carcinogenic HPV at enrolment but negative at follow-up ("cleared"), tested carcinogenic HPV negative at enrolment but positive at follow-up ("acquired"), and tested negative at both time points ( $\mathrm{Neg} / \mathrm{Neg})$. In right panels same groups are stratified by age. Time 0 * indicates start time of analysis, 9-21 months after enrolment

observed difference in the percentage of women aged $<30$ and $\geq 30$ who tested repeatedly positive for carcinogenic HPV but did not have persistence of a specific HPV genotype (32.0\% $v 12.3 \%)$.

\section{Strengths and weaknesses}

Our study had several strengths. The cohort in Guanacaste was a true population sample, with high participation rates at enrolment and good rates of follow-up. There were no obvious biases in follow-up in relation to the short term HPV status that would invalidate our findings. Finally, we relied on consensus review of histological end points to reduce misclassification.

There were also several limitations. Firstly, despite the size of the cohort and subcohort, there were few outcomes of precancer, resulting in unstable estimates of risk. Thus any losses to follow-up could influence the absolute estimates of cumulative incidence; however, as both HPV infection and cervical intraepithelial neoplasia grade II and III are asymptomatic, it is unlikely that there is a differential effect and the relative patterns are unlikely to change significantly. In addition, because of small numbers of outcomes, in most analyses we included grade II in our definition of cervical precancer and cancer. While histological grade II is the typical clinical threshold for treatment, there is an increasing awareness that it is an equivocal diagnosis of cervical precancer. ${ }^{21}$ Larger studies or pooled data analyses of existing cohorts, or both, are needed to more precisely describe these risks of cervical intraepithelial neoplasia grade III+ related to short term persistence.

Secondly, our analysis included only prevalently detected HPV infections. We did not have enough cases of cervical intraepithelial neoplasia grade II+ after incident infections to describe the risk after short term persistence. We therefore cannot apply our findings to determine the utility of measuring persistence of incident infections for risk stratification. This issue will become important if HPV testing is used in periodic screening in the coming years. Given that a proportion of prevalent infections will have already persisted for an unknown amount of time, and that the likelihood of continued persistence increases with duration of past persistence, ${ }^{12} 13$ it is reasonable to expect that monitoring incident infections for more than a year might be necessary to achieve similar risk stratification as has been achieved for prevalently detected infections. It is the duration of persistence - that is, the "age of the infection"- that predicts progression with specific HPV genotypes. ${ }^{13}$

Thirdly, we needed to make assumptions that compliance with scheduled clinic visits was independent of the risk of the end point to justify our statistical approach. Note that the standard Kaplan-Meier approach gives estimates of cumulative risk that are 
Table $5 \mid$ Three year and 5 year cumulative incidence rates of cervical intraepithelial neoplasia grade II or more severe (CIN II+) and CIN III+ after repeat measurements of carcinogenic human papillomavirus (HPV) at about 1 year interval (9-21 months) according to cytology results

\begin{tabular}{|c|c|c|c|c|c|c|c|c|c|c|c|c|}
\hline & \multirow[b]{3}{*}{$\begin{array}{c}\text { No of } \\
\text { women }\end{array}$} & \multicolumn{6}{|c|}{ CIN II+ } & \multicolumn{5}{|c|}{ CIN III+ } \\
\hline & & \multicolumn{3}{|c|}{3 year } & \multicolumn{3}{|c|}{5 year } & \multicolumn{2}{|r|}{3 year } & \multicolumn{3}{|c|}{5 year } \\
\hline & & $\begin{array}{l}\text { No of } \\
\text { cases }\end{array}$ & $\begin{array}{c}\text { Rate* }^{\star} \\
(95 \% \mathrm{Cl})\end{array}$ & $\begin{array}{l}\text { Rate ratio } \dagger \\
(95 \% \mathrm{Cl})\end{array}$ & $\begin{array}{l}\text { No of } \\
\text { cases }\end{array}$ & $\begin{array}{c}\text { Rate* }^{\star} \\
(95 \% \mathrm{Cl})\end{array}$ & $\begin{array}{l}\text { Rate ratio } \dagger \\
(95 \% \mathrm{Cl})\end{array}$ & $\begin{array}{l}\text { No of } \\
\text { cases }\end{array}$ & $\begin{array}{c}\text { Rate* }^{\star} \\
(95 \% \mathrm{Cl})\end{array}$ & $\begin{array}{l}\text { No of } \\
\text { cases }\end{array}$ & $\begin{array}{c}\text { Rate* }^{\star} \\
(95 \% \mathrm{Cl})\end{array}$ & $\begin{array}{c}\text { Rate ratio } \dagger \\
(95 \% \mathrm{Cl})\end{array}$ \\
\hline \multicolumn{13}{|c|}{ ASCUS or more severe cytology } \\
\hline $\begin{array}{l}\text { Carcinogenic HPV } \\
\text { persistence }\end{array}$ & 89 & 21 & $\begin{array}{c}28.79(18.12 \\
\text { to } 39.46)\end{array}$ & NA & 21 & $\begin{array}{c}28.79(18.12 \\
\text { to } 39.46)\end{array}$ & NA & 11 & $\begin{array}{c}15.00(6.53 \\
\text { to } 23.48)\end{array}$ & 11 & $\begin{array}{c}15.00(6.53 \\
\text { to } 23.48)\end{array}$ & NA \\
\hline $\begin{array}{l}\text { Specific genotype } \\
\text { persistence }\end{array}$ & 73 & 21 & $\begin{array}{c}34.93(22.49 \\
\text { to } 47.36)\end{array}$ & NA & 21 & $\begin{array}{c}34.93(22.49 \\
\text { to } 47.36)\end{array}$ & NA & 11 & $\begin{array}{c}18.73(8.25 \\
\text { to } 29.20)\end{array}$ & 11 & $\begin{array}{c}18.73(8.25 \\
\text { to } 29.20)\end{array}$ & NA \\
\hline Non-persistence & 16 & 0 & 0.00 & NA & 0 & 0.00 & NA & 0 & 0.00 & 0 & 0.00 & NA \\
\hline HP 16 persistence & 17 & 8 & $\begin{array}{c}58.18(30.88 \\
\text { to } 85.48)\end{array}$ & NA & 8 & $\begin{array}{l}58.18(30.88 \\
\text { to } 85.48)\end{array}$ & NA & 4 & $\begin{array}{c}27.94(3.29 \\
\text { to } 52.59)\end{array}$ & 4 & $\begin{array}{c}27.94(3.29 \\
\text { to } 52.59)\end{array}$ & NA \\
\hline HPV 18 persistence & 9 & 3 & $\begin{array}{c}37.78(2.91 \\
\text { to } 72.65)\end{array}$ & NA & 3 & $\begin{array}{c}37.78(2.91 \\
\text { to } 72.65)\end{array}$ & NA & 1 & $\begin{array}{c}11.11(-9.42 \\
\text { to } 31.64)\end{array}$ & 1 & $\begin{array}{c}11.11(-9.42 \\
\text { to } 31.64)\end{array}$ & NA \\
\hline $\begin{array}{l}\text { Carcinogenic HPV } \\
\text { persistence (not } 16 \\
\text { and 18) }\end{array}$ & 63 & 10 & $\begin{array}{c}19.62(8.51 \\
\text { to } 30.73)\end{array}$ & NA & 10 & $\begin{array}{c}19.62(8.51 \\
\text { to } 30.73)\end{array}$ & NA & 6 & $\begin{array}{c}11.80(2.71 \\
\text { to } 20.90)\end{array}$ & 6 & $\begin{array}{c}11.80(2.71 \\
\text { to } 20.90)\end{array}$ & NA \\
\hline Acquisition & 31 & 1 & $\begin{array}{c}3.23(-2.99 \\
\text { to } 9.45)\end{array}$ & NA & 1 & $\begin{array}{c}3.23(-2.99 \\
\text { to } 9.45)\end{array}$ & NA & 1 & $\begin{array}{l}3.23(-2.99 \\
\text { to } 9.45)\end{array}$ & 1 & $\begin{array}{c}3.23(-2.99 \\
\text { to } 9.45)\end{array}$ & NA \\
\hline $\begin{array}{l}\text { Clearance } \\
\text { (reference) } \ddagger\end{array}$ & 30 & 0 & 0.00 & NA & 0 & 0.00 & NA & 0 & 0.00 & 0 & 0.00 & NA \\
\hline HPV negative & 115 & 3 & $\begin{array}{c}2.86(-0.36 \\
\text { to } 6.07)\end{array}$ & NA & 3 & $\begin{array}{c}2.86(-0.36 \\
\text { to } 6.07)\end{array}$ & NA & 2 & $\begin{array}{c}2.00(-2.00 \\
\text { to } 4.76)\end{array}$ & 2 & $\begin{array}{c}2.00(-2.00 \\
\text { to } 4.76)\end{array}$ & NA \\
\hline \multicolumn{13}{|l|}{ Negative cytology } \\
\hline $\begin{array}{l}\text { Carcinogenic HPV } \\
\text { persistence }\end{array}$ & 162 & 16 & $\begin{array}{c}11.47(6.15 \\
\text { to } 16.79)\end{array}$ & $\begin{array}{l}8.24(2.44 \\
\text { to } 27.83)\end{array}$ & 20 & $\begin{array}{l}23.22(9.00 \\
\text { to } 37.44)\end{array}$ & $\begin{array}{c}12.38(3.92 \\
\text { to } 39.06)\end{array}$ & 12 & $\begin{array}{l}9.12(4.19 \\
\text { to } 14.05)\end{array}$ & 16 & $\begin{array}{c}21.18(6.72 \\
\text { to } 35.64)\end{array}$ & $\begin{array}{l}43.21(5.45 \\
\text { to } 342.72)\end{array}$ \\
\hline $\begin{array}{l}\text { Specific genotype } \\
\text { persistence }\end{array}$ & 129 & 16 & $\begin{array}{l}14.50(7.89 \\
\text { to } 21.10)\end{array}$ & $\begin{array}{l}8.29(2.40 \\
\text { to } 28.59)\end{array}$ & 20 & $\begin{array}{l}28.86(11.91 \\
\text { to } 44.80)\end{array}$ & $\begin{array}{c}15.11(4.87 \\
\text { to } 46.90)\end{array}$ & 12 & $\begin{array}{l}11.61(5.42 \\
\text { to } 17.80)\end{array}$ & 16 & $\begin{array}{c}25.94(9.11 \\
\text { to } 42.77)\end{array}$ & $\begin{array}{l}52.92(6.74 \\
\text { to } 415.20)\end{array}$ \\
\hline Non-persistence & 33 & 0 & 0.00 & 0.00 & 0 & 0.00 & 0.00 & 0 & 0.00 & 0 & 0.00 & 0.00 \\
\hline HP 16 persistence & 36 & 10 & $\begin{array}{c}32.76(15.92 \\
\text { to } 49.60)\end{array}$ & $\begin{array}{l}23.52(6.82 \\
\text { to } 81.1)\end{array}$ & 10 & $\begin{array}{c}32.76(15.92 \\
\text { to } 49.60)\end{array}$ & $\begin{array}{l}17.46(5.81 \\
\text { to } 52.45)\end{array}$ & 8 & $\begin{array}{l}28.80(11.89 \\
\text { to } 45.72)\end{array}$ & 8 & $\begin{array}{l}28.80(11.89 \\
\text { to } 45.72)\end{array}$ & $\begin{array}{l}58.76(7.63 \\
\text { to } 452.57)\end{array}$ \\
\hline HPV 18 persistence & 9 & 0 & 0.00 & 0.00 & 0 & 0.00 & 0.00 & 0 & 0.00 & 0 & 0.00 & 0.00 \\
\hline $\begin{array}{l}\text { Carcinogenic HPV } \\
\text { persistence } \\
\text { (not } 16 \text { and 18) }\end{array}$ & 117 & 6 & $\begin{array}{l}5.91(1.31 \\
\text { to } 10.51)\end{array}$ & $\begin{array}{l}4.25(1.08 \\
\text { to } 16.68)\end{array}$ & 10 & $\begin{array}{c}20.25(3.76 \\
\text { to } 36.74)\end{array}$ & $\begin{array}{c}10.79(3.04 \\
\text { to } 38.37)\end{array}$ & 4 & $\begin{array}{l}4.08(0.16 \\
\text { to } 8.00)\end{array}$ & 8 & $\begin{array}{c}18.70(2.03 \\
\text { to } 35.36)\end{array}$ & $\begin{array}{c}38.14(4.45 \\
\text { to } 327.05)\end{array}$ \\
\hline Acquisition & 88 & 3 & $\begin{array}{c}3.69(-0.44 \\
\text { to } 7.81)\end{array}$ & $\begin{array}{l}2.65(0.54 \\
\text { to } 12.95)\end{array}$ & 4 & $\begin{array}{c}5.01(0.20 \\
\text { to } 9.82)\end{array}$ & $\begin{array}{l}2.67(0.68 \\
\text { to } 10.47)\end{array}$ & 1 & $\begin{array}{c}1.14(-1.08 \\
\text { to } 3.35)\end{array}$ & 1 & $\begin{array}{c}2.49(-0.93 \\
\text { to } 5.91)\end{array}$ & $\begin{array}{l}5.08(0.47 \\
\text { to } 55.45) \\
\end{array}$ \\
\hline $\begin{array}{l}\text { Clearance } \\
\text { (reference) } \ddagger\end{array}$ & 236 & 3 & $\begin{array}{c}1.39(-0.18 \\
\text { to } 2.96)\end{array}$ & 1.00 & 4 & $\begin{array}{c}1.88(0.05 \\
\text { to } 3.70)\end{array}$ & 1.00 & 0 & 0.00 & 1 & $\begin{array}{c}0.49(-0.47 \\
\text { to } 1.45)\end{array}$ & 1.00 \\
\hline HPV negative & 1449 & 4 & $\begin{array}{c}0.32(0.01 \\
\text { to } 0.64)\end{array}$ & $\begin{array}{c}0.23(0.05 \\
\text { to } 1.03)\end{array}$ & 4 & $\begin{array}{l}0.32(0.01 \\
\text { to } 0.64)\end{array}$ & $\begin{array}{l}0.17(0.04 \\
\text { to } 0.68)\end{array}$ & 2 & $\begin{array}{c}0.16(-0.06 \\
\text { to } 0.39)\end{array}$ & 2 & $\begin{array}{c}0.16(-0.06 \\
\text { to } 0.39)\end{array}$ & $\begin{array}{c}0.33(0.03 \\
\text { to } 3.63)\end{array}$ \\
\hline
\end{tabular}

ASCUS=atypical squamous cells of undetermined significance.

${ }^{\star}$ Cumulative incidence rates.

†Cumulative incidence rate ratio; when no events of CIN II+ occurred in reference group, this could not be calculated (NA).

¥Women who tested positive and then negative for carcinogenic HPV ("clearance").

too low: it assumes that women who are not diagnosed with an end point have not experienced the end point, even though here the diagnosis is delayed simply because they did not appear during the interval for their visit.

Because of less than perfect sensitivity of colposcopy, ${ }^{31}$ we cannot truly distinguish between missed prevalent and incident disease, nor can we separate missed miniscule foci of prevalent disease ensuring viral persistence versus viral persistence predicting the progression to cervical intraepithelial neoplasia grade II+. Many histologically confirmed cases of grade II+ $(\mathrm{n}=144)$ were diagnosed during the enrolment phase. It seems likely that some cases detected during follow-up undoubtedly were present but missed by enrolment colposcopy, just as in routine clinical practice. The purpose of our analysis, however, was to describe the risk of having or developing cervical intraepithelial neoplasia grade II+ after patterns of HPV detection and to determine the best format of detection with HPV genotyping rather than making any distinctions about the "origins" of the viral persistence or cervical intraepithelial neoplasia grade II+.

\section{Clinical implications}

Monitoring of prevalently detected HPV infections for short term persistence might be useful for identifying the women positive for carcinogenic HPV at risk of cervical intraepithelial neoplasia grade II+ in the following years. 
Table 6 |Three year and 5 year cumulative incidence rates of cervical intraepithelial neoplasia grade II or more severe (CIN II+) and CIN III+ after repeat measurements of carcinogenic human papillomavirus (HPV) at about 1 year interval (9-21 months) according to whether women underwent colposcopy during time interval

\begin{tabular}{|c|c|c|c|c|c|c|c|c|c|c|c|c|}
\hline & \multirow[b]{3}{*}{$\begin{array}{c}\text { No of } \\
\text { women }\end{array}$} & \multicolumn{6}{|c|}{ CIN II+ } & \multicolumn{5}{|c|}{ CIN III+ } \\
\hline & & \multicolumn{3}{|c|}{3 year } & \multicolumn{3}{|c|}{5 year } & \multicolumn{2}{|r|}{3 year } & \multicolumn{3}{|c|}{5 year } \\
\hline & & $\begin{array}{l}\text { No of } \\
\text { cases }\end{array}$ & $\begin{array}{c}\text { Rate* }^{\star} \\
(95 \% \mathrm{Cl})\end{array}$ & $\begin{array}{c}\text { Rate ratio } \dagger \\
(95 \% \mathrm{Cl})\end{array}$ & $\begin{array}{l}\text { No of } \\
\text { cases }\end{array}$ & $\begin{array}{l}\text { Rate* }^{\star} \\
(95 \% \mathrm{Cl})\end{array}$ & $\begin{array}{c}\text { Rate ratio } \dagger \\
(95 \% \mathrm{Cl})\end{array}$ & $\begin{array}{l}\text { No of } \\
\text { cases }\end{array}$ & $\begin{array}{c}\text { Rate* }^{\star} \\
(95 \% \mathrm{Cl})\end{array}$ & $\begin{array}{l}\text { No of } \\
\text { cases }\end{array}$ & $\begin{array}{c}\text { Rate* }^{\star} \\
(95 \% \mathrm{Cl})\end{array}$ & $\begin{array}{c}\text { Rate ratio† } \\
(95 \% \mathrm{Cl})\end{array}$ \\
\hline \multicolumn{13}{|l|}{ Colposcopy } \\
\hline $\begin{array}{l}\text { Carcinogenic HPV } \\
\text { persistence }\end{array}$ & 144 & 27 & $\begin{array}{l}21.56(14.28 \\
\text { to } 28.84)\end{array}$ & $\begin{array}{c}11.31(3.50 \\
\text { to } 36.54)\end{array}$ & 28 & $\begin{array}{l}22.48(15.07 \\
\text { to } 29.89)\end{array}$ & $\begin{array}{c}11.80(3.66 \\
\text { to } 38.02)\end{array}$ & 17 & $\begin{array}{c}14.37(7.97 \\
\text { to } 20.78)\end{array}$ & 18 & $\begin{array}{c}15.38(8.75 \\
\text { to } 22.01)\end{array}$ & NA \\
\hline $\begin{array}{l}\text { Specific genotype } \\
\text { persistence }\end{array}$ & 115 & 27 & $\begin{array}{l}27.14(18.28 \\
\text { to } 35.99)\end{array}$ & $\begin{array}{c}14.24(4.42 \\
\text { to } 45.85)\end{array}$ & 28 & $\begin{array}{l}28.35(19.33 \\
\text { to } 37.38)\end{array}$ & $\begin{array}{c}14.88(4.63 \\
\text { to } 47.79)\end{array}$ & 17 & $\begin{array}{c}18.38(10.34 \\
\text { to } 26.41)\end{array}$ & 18 & $\begin{array}{l}19.74(11.40 \\
\text { to } 28.07)\end{array}$ & NA \\
\hline Non-persistence & 29 & 0 & 0.00 & 0.00 & 0 & 0.00 & 0.00 & 0 & 0.00 & 0 & 0.00 & NA \\
\hline HP 16 persistence & 35 & 11 & $\begin{array}{l}37.45(19.58 \\
\text { to } 55.33)\end{array}$ & $\begin{array}{c}19.65(5.80 \\
\text { to } 66.58)\end{array}$ & 11 & $\begin{array}{l}37.45(19.58 \\
\text { to } 55.33)\end{array}$ & $\begin{array}{c}19.65(5.80 \\
\text { to } 66.58)\end{array}$ & 7 & $\begin{array}{c}26.79(9.38 \\
\text { to } 44.20)\end{array}$ & 7 & $\begin{array}{c}26.79(9.38 \\
\text { to } 44.20)\end{array}$ & NA \\
\hline HPV 18 persistence & 11 & 3 & $\begin{array}{l}27.27(0.95 \\
\text { to } 53.59)\end{array}$ & $\begin{array}{c}14.31(3.26 \\
\text { to } 62.90)\end{array}$ & 3 & $\begin{array}{c}27.27(0.95 \\
\text { to } 53.59)\end{array}$ & $\begin{array}{c}14.31(3.26 \\
\text { to } 62.90)\end{array}$ & 1 & $\begin{array}{c}9.09(-7.90 \\
\text { to } 26.08)\end{array}$ & 1 & $\begin{array}{c}9.09(-7.90 \\
\text { to } 26.08)\end{array}$ & NA \\
\hline $\begin{array}{l}\text { Carcinogenic HPV } \\
\text { persistence (not } 16 \text { and } \\
\text { 18) }\end{array}$ & 98 & 13 & $\begin{array}{c}15.55(7.73 \\
\text { to } 23.36)\end{array}$ & $\begin{array}{l}8.16(2.38 \\
\text { to } 27.91)\end{array}$ & 14 & $\begin{array}{c}16.87(8.76 \\
\text { to } 24.97)\end{array}$ & $\begin{array}{l}8.85(2.61 \\
\text { to } 30.02)\end{array}$ & 9 & $\begin{array}{c}11.00(4.17 \\
\text { to } 17.82)\end{array}$ & 10 & $\begin{array}{c}12.39(5.15 \\
\text { to } 19.63)\end{array}$ & NA \\
\hline Acquisition & 79 & 2 & $\begin{array}{c}2.53(-0.93 \\
\text { to } 6.00)\end{array}$ & $\begin{array}{l}1.33(0.23 \\
\text { to } 7.80)\end{array}$ & 3 & $\begin{array}{c}4.16(-0.49 \\
\text { to } 8.80)\end{array}$ & $\begin{array}{l}2.18(0.45 \\
\text { to } 10.63)\end{array}$ & 2 & $\begin{array}{c}2.53(-0.93 \\
\text { to } 6.00)\end{array}$ & 3 & $\begin{array}{l}4.16(-0.49 \\
\text { to } 8.80)\end{array}$ & NA \\
\hline Clearance (reference) $\ddagger$ & 170 & 3 & $\begin{array}{c}1.91(-0.23 \\
\text { to } 4.05)\end{array}$ & 1.00 & 3 & $\begin{array}{l}1.91(-0.23 \\
\text { to } 4.05)\end{array}$ & 1.00 & 0 & 0.00 & 0 & 0.00 & NA \\
\hline HPV negative & 985 & 5 & $\begin{array}{l}0.58(0.07 \\
\text { to } 1.09)\end{array}$ & $\begin{array}{c}0.30(0.07 \\
\text { to } 1.26)\end{array}$ & 5 & $\begin{array}{l}0.58(0.07 \\
\text { to } 1.09)\end{array}$ & $\begin{array}{c}0.30(0.07 \\
\text { to } 1.26)\end{array}$ & 4 & $\begin{array}{c}0.46(0.01 \\
\text { to } 0.91)\end{array}$ & 4 & $\begin{array}{c}0.46(0.01 \\
\text { to } 0.91)\end{array}$ & NA \\
\hline \multicolumn{13}{|l|}{ No colposcopy } \\
\hline $\begin{array}{l}\text { Carcinogenic HPV } \\
\text { persistence }\end{array}$ & 116 & 11 & $\begin{array}{c}11.14(4.85 \\
\text { to } 17.42)\end{array}$ & NA & 14 & $\begin{array}{c}25.73(7.64 \\
\text { to } 43.81)\end{array}$ & $\begin{array}{l}25.21(3.17 \\
\text { to } 200.37)\end{array}$ & 7 & $\begin{array}{l}7.30(2.02 \\
\text { to } 12.57)\end{array}$ & 10 & $\begin{array}{c}22.51(3.93 \\
\text { to } 41.10)\end{array}$ & $\begin{array}{c}22.06(2.65 \\
\text { to } 183.37)\end{array}$ \\
\hline $\begin{array}{l}\text { Specific genotype } \\
\text { persistence }\end{array}$ & 94 & 11 & $\begin{array}{c}13.79(6.11 \\
\text { to } 21.46)\end{array}$ & NA & 14 & $\begin{array}{l}33.98(10.10 \\
\text { to } 57.86)\end{array}$ & 33.30 & 7 & $\begin{array}{l}9.13(2.58 \\
\text { to } 15.67)\end{array}$ & 10 & $\begin{array}{c}30.41(5.50 \\
\text { to } 55.31)\end{array}$ & $\begin{array}{c}29.80(3.59 \\
\text { to } 247.02)\end{array}$ \\
\hline Non-persistence & 22 & 0 & 0.00 & NA & 0 & 0.00 & 0.00 & 0 & 0.00 & 0 & 0.00 & 0.00 \\
\hline HPV 16 persistence & 20 & 8 & $\begin{array}{c}45.36(21.77 \\
\text { to } 68.94)\end{array}$ & NA & 8 & $\begin{array}{c}45.36(21.77 \\
\text { to } 68.94)\end{array}$ & $\begin{array}{c}44.45(5.91 \\
\text { to } 334.45)\end{array}$ & 6 & $\begin{array}{c}35.71(12.44 \\
\text { to } 58.99)\end{array}$ & 6 & $\begin{array}{l}35.71(12.44 \\
\text { to } 58.99)\end{array}$ & $\begin{array}{l}35.00(4.48 \\
\text { to } 273.52)\end{array}$ \\
\hline HPV 18 persistence & 7 & 0 & 0.00 & NA & 0 & 0.00 & 0.00 & 0 & 0.00 & 0 & 0.00 & 0.00 \\
\hline $\begin{array}{l}\text { Carcinogenic HPV } \\
\text { persistence } \\
\text { (not } 16 \text { and 18) } \\
\end{array}$ & 89 & 3 & $\begin{array}{c}3.66(-0.44 \\
\text { to } 7.76)\end{array}$ & NA & 6 & $\begin{array}{c}20.92(0.49 \\
\text { to } 41.34)\end{array}$ & $\begin{array}{l}20.50(2.32 \\
\text { to } 181.49)\end{array}$ & 1 & $\begin{array}{c}1.12(-1.07 \\
\text { to } 3.31)\end{array}$ & 4 & $\begin{array}{c}18.83(-1.92 \\
\text { to } 39.59)\end{array}$ & $\begin{array}{c}18.46(1.97 \\
\text { to } 173.34)\end{array}$ \\
\hline Acquisition & 46 & 2 & $\begin{array}{c}4.97(-1.01 \\
\text { to } 11.74)\end{array}$ & NA & 2 & $\begin{array}{c}4.97(-1.01 \\
\text { to } 11.74)\end{array}$ & $\begin{array}{c}4.87(0.45 \\
\text { to } 52.59)\end{array}$ & 0 & 0.00 & 0 & 0.00 & 0.00 \\
\hline Clearance (reference) $†$ & 112 & 0 & 0.00 & NA & 1 & $\begin{array}{c}1.02(-0.97 \\
\text { to } 3.01)\end{array}$ & 1.00 & 0 & 0.00 & 1 & $\begin{array}{c}1.02(-0.97 \text { to } \\
3.01)\end{array}$ & 1.00 \\
\hline HPV negative & 630 & 2 & $\begin{array}{l}0.35(-0.14 \\
\text { to } 0.83)\end{array}$ & NA & 2 & $\begin{array}{c}0.35(-0.14 \\
\text { to } 0.83)\end{array}$ & $\begin{array}{c}0.34(0.03 \\
\text { to } 3.75)\end{array}$ & 0 & 0.00 & 0 & 0.00 & 0.00 \\
\hline
\end{tabular}

${ }^{*}$ Cumulative incidence rates.

tCumulative incidence rate ratio; when no events of CIN II+ occurred in reference group, this could not be calculated (NA).

fWomen who tested positive and then negative for carcinogenic HPV ("clearance").

A validated method of HPV genotyping might allow clinically useful monitoring of HPV 16 and perhaps HPV 18, beginning at age 25 when the risk of precancer becomes non-trivial. For women between the ages of 25-30, it will be especially important for clinicians to wait for evidence of persistence rather than act on the first positive test for HPV 16 and 18. It is less clear whether there is clinical utility for detecting persistence of a specific HPV genotype among those repeatedly positive for carcinogenic HPV genotypes other than HPV 16 and 18. Specifically monitoring the other carcinogenic HPV genotypes does differentiate women with persistent specific HPV infections who are at risk of cervical intraepithelial neoplasia grade II+ from those who test positive for different HPV genotypes and are not at risk of grade II+. Most women who tested repeatedly positive for carcinogenic HPV had viral persistence, although less so for women under 30. As a consequence, detection of persistence of a specific HPV genotype of other carcinogenic genotypes did not provide significant risk stratification above that achieved by pooled detection of all other carcinogenic genotypes. Thus, it might be more practical to specifically monitor only the riskiest HPV genotypes, such as HPV 16 and 18, and detect the other carcinogenic genotypes in aggregate, accepting the trade-off that a fraction of repeat positives for other carcinogenic genotypes do not represent HPV persistence in exchange for greater reliability for detecting those that do. Further evaluation of these trade-offs and accuracy versus ease of use, ${ }^{32}$ with consideration of any cost differences, is warranted. 


\section{WHAT IS ALREADY KNOWN ON THIS TOPIC}

\section{HPV persistence increases the risk of cervical abnormalities}

\section{WHAT THIS STUDY ADDS}

Repeat testing (versus a one time test) for carcinogenic HPV improves the positive predictive value while maintaining excellent negative predictive values for cervical intraepithelial neoplasia grade II or more severe (II+) and grade $\mathrm{II}+$

Women with short term persistent HPV 16 are at high risk for cervical intraepithelial neoplasia grade $\mathrm{II}+$ and $\mathrm{III}$

There was little difference in the cumulative incidence of cervical intraepithelial neoplasia grade II+ and III+ between testing positive twice for any carcinogenic HPV genotype (same or different genotype) versus testing positive twice for the same carcinogenic genotype, particularly for women aged $\geq 30$
7 Cuzick J, Clavel C, Petry KU, Meijer CJ, Hoyer H, Ratnam S, et al. Overview of the European and North American studies on HPV testing in primary cervical cancer screening. Int J Cancer 2006;119:1095-101.

8 IARC. Cervix cancer screening. IARC handbooks of cancer prevention Lyon: IARC Press, 2005.

9 Cuzick J, Mayrand MH, Ronco G, Snijders P, Wardle J. Chapter 10: New dimensions in cervical cancer screening. Vaccine 2006;24(suppl 3):S90-7.

10 Khan MJ, Castle PE, Lorincz AT, Wacholder S, Sherman M, Scott DR, et al. The elevated 10-year risk of cervical precancer and cancer in women with human papillomavirus (HPV) type 16 or 18 and the possible utility of type-specific HPV testing in clinical practice. / Nat Cancer Inst 2005;20;97:1072-9.

11 Wright TC Jr, Massad LS, Dunton CJ, Spitzer M, Wilkinson EJ, Solomon D. 2006 consensus guidelines for the management of women with abnormal cervical cancer screening tests. Am J Obstet Gynecol 2007;197:346-55.

12 Plummer M, Schiffman M, Castle PE, Maucort-Boulch D, Wheeler CM. A 2-year prospective study of human papillomavirus persistence among women with a cytological diagnosis of atypical squamous cells of undetermined significance or low-grade squamous intraepithelial lesion. J Infect Dis 2007;195:1582-9.

13 Rodriguez AC, Schiffman M, Herrero R, Wacholder S, Hildesheim A, Castle PE, et al. Rapid clearance of human papillomavirus and implications for clinical focus on persistent infections. J Natl Cancer Inst 2008;100:513-7.

manuscript. The following individuals participated in the Proyecto

Epidemiológico Guanacaste (PEG) Group: M Schiffman, project officer;

A Hildesheim, co-project officer: S Wacholder, statistician; M Sherman,

pathologist, at the National Cancer Institute, NIH, Bethesda MD; MC Bratti, principal investigator; R Herrero, co-principal investigator; AC Rodríguez, assistant principal investigator; J Morales, colposcopist; M Alfaro, cytopathologist, and D Guillén, histopathologist, at the Costa Rican Foundation for Health Sciences, San José, Costa Rica; M Hutchinson, cytologist, at Women and Infants' Hospital, Providence, Rl; and J Schussler, senior programmer and analyst, at Information Management Services, Silver Spring, MD.

Contributors: PEC was the chief analyst and is guarantor. MS, SW, and RH designed the study. MS, AH, RH, ACR, MA, JM, and DG initiated the study. $A C R$ and $\mathrm{RH}$ were responsible for the recruitment and follow-up of participants. RDB was responsible for the HPV testing. MA, DG, MES, and DS undertook cytological interpretations and histological diagnoses. PEC, MS, ACR, and SW were responsible for the statistical analysis. PEC wrote the first draft of the paper. All authors contributed to and approved the final version of the paper.

Funding: This study was supported by the National Institutes of Health (N01-CP-21081, N01-CP-33061, N01-CP-40542, N01-CP-50535, N01CP-81023, intramural programme, CA78527 to RB). The Guanacaste cohort was partly funded by the intramural research programme of the National Cancer Institute, National Institutes of Health, Department of Health and Human Services. ACR was supported by an appointment to the senior fellowship programme at the National Institutes of Health. The programme is administered by the Oak Ridge Institute for Science and Education through an interagency agreement between the US Department of Energy and the National Institutes of Health. The sponsors had no role in the study design, data collection, data analysis, data interpretation, or the writing of the report. Competing interests: None declared.

Ethical approval: This study was approved by the Ministry of Health of Costa Rica and the US National Cancer Institute and informed consent was given by all patients.

1 Castle PE, Wheeler CM, Solomon D, Schiffman M, Peyton CL. Interlaboratory reliability of hybrid capture 2. Am J Clin Pathol 2004;122:238-45.

2 Carozzi FM, Del Mistro A, Confortini M, Sani C, Puliti D, Trevisan R, et al. Reproducibility of HPV DNA testing by hybrid capture 2 in a screening setting. Am J Clin Pathol 2005;124:716-21.

3 Arbyn M, Sasieni P, Meijer CJ, Clavel C, Koliopoulos G, Dillner J. Chapter 9: Clinical applications of HPV testing: a summary of metaanalyses. Vaccine 2006;24(suppl 3):S78-89.

4 Mayrand MH, Duarte-Franco E, Rodrigues I, Walter SD, Hanley J, Ferenczy A, et al. Human papillomavirus DNA versus Papanicolaou screening tests for cervical cancer. N Engl J Med 2007;357:1579-88.

5 Naucler P, Ryd W, Tornberg S, Strand A, Wadell G, Elfgren K, et al. Human papillomavirus and Papanicolaou tests to screen for cervical cancer. N Engl/ Med 2007:357:1589-97.

6 Bulkmans N, Berkhof J, Rozendaal L, van Kemenade FJ, Boeke A, Bulk S, et al. Human papillomavirus DNA testing for the detection of cervical intraepithelial neoplasia grade 3 and cancer: 5 -year followup of a randomised controlled implementation trial. Lancet 2007;370:1764-72.
14 Koshiol J, Lindsay L, Pimenta JM, Poole C, Jenkins D, Smith JS. Persistent human papillomavirus infection and cervical neoplasia: a systematic review and meta-analysis. Am J Epidemiol 2008;168:123-37.

15 Bratti MC, Rodriguez AC, Schiffman M, Hildesheim A, Morales J, Alfaro $M$, et al. Description of a seven-year prospective study of human papillomavirus infection and cervical neoplasia among 10 000 women in Guanacaste, Costa Rica [Descripcion de un estudio prospectivo de siete anos sobre la infeccion por el virus del papiloma humano y el cancer cervicouterino en 10000 mujeres de Guanacaste, Costa Rica]. Rev Panam Salud Publica 2004;15:75-89.

16 Herrero R, Schiffman MH, Bratti C, Hildesheim A, Balmaceda I, Sherman ME, et al. Design and methods of a population-based natural history study of cervical neoplasia in a rural province of Costa Rica: the Guanacaste Project. Rev Panam Salud Publica 1997;1:362-75.

17 Castle PE, Schiffman M, Gravitt PE, Kendall H, Fishman S, Dong H, et al. Comparisons of HPV DNA detection by MY09/11 PCR methods. J Med Virol 2002;68:417-23.

18 Rodriguez AC, Schiffman M, Herrero R, Wacholder S, Hildesheim A Castle PE, et al. Rapid clearance of HPV should lead to clinical focus on persistent infections. I Natl Cancer Inst 2008;100:513-7.

19 Munoz N, Bosch FX, de Sanjose S, Herrero R, Castellsague X, Shah KV, et al. Epidemiologic classification of human papillomavirus types associated with cervical cancer. N Engl J Med 2003;348:518-27.

20 Smith JS, Lindsay L, Hoots B, Keys J, Franceschi S, Winer R, et al. Human papillomavirus type distribution in invasive cervical cancer and high-grade cervical lesions: a meta-analysis update. Int J Cancer 2007;121:621-32.

21 Castle PE, Stoler MH, Solomon D, Schiffman M. The relationship of community biopsy-diagnosed cervical intraepithelial neoplasia grade 2 to the quality control pathology-reviewed diagnoses: an ALTS report. Am J Clin Pathol 2007;127:805-15.

22 Schiffman M, Castle PE, Jeronimo J, Rodriguez AC, Wacholder S Human papillomavirus and cervical cancer. Lancet 2007;370:890-907

23 Kulasingam SL, Hughes JP, Kiviat NB, Mao C, Weiss NS, Kuypers JM, et al. Evaluation of human papillomavirus testing in primary screening for cervical abnormalities: comparison of sensitivity, specificity, and frequency of referral. JAMA 2002;288:1749-57.

24 Bulkmans NW, Berkhof J, Bulk S, Bleeker MC, van Kemenade FJ, Rozendaal L, et al. High-risk HPV type-specific clearance rates in cervical screening. Br J Cancer 2007;96:1419-24.

25 Bulk S, Berkhof J, Rozendaal L, Fransen Daalmeijer NC, Gok M, de Schipper FA, et al. The contribution of HPV18 to cervical cancer is underestimated using high-grade CIN as a measure of screening efficiency. Br J Cancer 2007;96:1234-6.

26 Wang SS, Sherman ME, Hildesheim A, Lacey JV Jr, Devesa S. Cervical adenocarcinoma and squamous cell carcinoma incidence trends among white women and black women in the United States for 1976 2000. Cancer 2004;100:1035-44.

27 Bray F, Carstensen B, Moller H, Zappa M, Zakelj MP, Lawrence G, et al. Incidence trends of adenocarcinoma of the cervix in 13 European countries. Cancer Epidemiol Biomarkers Prev 2005;14:2191-9.

28 Kjaer SK, van den Brule AJ, Paull G, Svare El, Sherman ME, Thomsen BL, et al. Type specific persistence of high risk human 
papillomavirus (HPV) as indicator of high grade cervical squamous intraepithelial lesions in young women: population based prospective follow up study. BMJ 2002;325:572.

29 Kjaer S, Hogdall E, Frederiksen K, Munk C, van den BA, Svare E, et al. The absolute risk of cervical abnormalities in high-risk human papillomavirus-positive, cytologically normal women over a 10-year period. Cancer Res 2006;66:10630-6.

30 Castle PE, Schiffman M, Herrero R, Hildesheim A, Rodriguez AC, Bratti MC, et al. A prospective study of age trends in cervical human papillomavirus acquisition and persistence in guanacaste, costa rica. J Infect Dis 2005;191:1808-16.

31 Jeronimo J, Schiffman M. Colposcopy at a crossroads. Am J Obstet Gynecol 2006;195:349-53.

32 Castle PE. Invited commentary: is monitoring of human papillomavirus infection for viral persistence ready for use in cervical cancer screening? Am J Epidemiol 2008;168:138-44.

Accepted: 15 April 2009 